\title{
Measurement and characterisation of the Digital Divide of Spanish regions at enterprise level. A comparative analysis with the European context.
}

Francisca Ruiz- Rodríguez, Angel Luis Lucendo-Monedero, Reyes González-Relaño

Universidad de Sevilla, c/Maria de Padilla s/n, 41004, Sevilla, Spain

Post-print version. Article published in:Telecommunications Policy. Volume 42, Issue

3, April 2018, Pages 187-211. https://doi.org/10.1016/j.telpol.2017.11.007

\begin{abstract}
Until now, a reduced number of research is observed on the adoption and use of ICTs in enterprises and on the Digital Divide (DD) between them at regional scale in Europe. What is meant by DD are the differences in the levels of digital development of the enterprises; being the digital development the degree of adoption and use of ICTs and e-commerce by the firms. The aim of this piece of work is to characterise and measure the DD in the Spanish regions and those in the countries of the European Union based on the data of their enterprises with more than 10 employees which have used ICTs. The methodology is developed in the following stages: 1) Construction of a synthetic index of digital development (Enterprise Digital Development Index -EDDI-) for countries in the EU and Spanish regions. The production of this index is carried out based on the factors obtained with the factor analysis (FA) with the aim of identifying the key variables which define the different EDDI components. These variables come from the "Community survey on ICT usage and e-commerce in enterprises" of Eurostat. 2) Classification of Spanish regions into the groups of European countries with a similar level of EDDI components based on the discriminant analysis. Those groups are previously obtained by using cluster analysis. And 3) Comparative analysis of the DD between the Spanish regions and those in countries of the EU based on EDDI components and the identified groups. The study provides a synthetic index (EDDI) at European scale comprising 3 dimensions which permits obtaining: i) a ranking from more to less digital development of countries and regions permitting the measurement of the DD among them is established; and ii) a typology of European countries and Spanish regions is defined according to the 3 dimensions of EDDI. The main results of this piece of work show that the Spanish regions at enterprise level: i) are in a medium or higher level of digital development than their European counterparts, presenting, furthermore, a lower DD between them in relation to what happens in European countries; ii) stand out for having a higher digital inclusion than European countries in the ICTs related to infrastructures of internet access and for the interaction with the public authorities; and iii) have a digital development deficit in the integration of ICTs for e-commerce.
\end{abstract}

\section{Keywords}

Spanish regions, Enterprise, Information and Communication Technology (ICT), Digital Divide (DD), Multivariate Analysis, European Union 


\section{Highlights}

1. Original contribution to regional literature about ICTs at enterprise level.

2. It presents a methodology to measure the level of digital development and the DD.

3. Spanish regions have a medium-high level of digital development in Europe.

4. The DD of the Spanish regions is lower than that of European countries.

5. Spanish regions stand out in the provision of fundamental ICTs and the interrelation with public authorities. 


\section{INTRODUCTION}

From the end of the $20^{\text {th }}$ century, it is stated that the Information and Communication Technologies (ICT) have a positive impact on the productivity and competitiveness of enterprises (Mason and Hacker, 2003; Hernaus, et al., 2012; Skrinjar, et al., 2010) and the capacity for development of innovation and transformation of the rest of economic sectors (Carlsson, et al., 2002). By ICTs, it is understood the set of tools, normally of an electronic nature, used to collect, store, process, diffuse and transmit information. This brings together both physical devices (computer equipment, telecommunication networks, terminals, etc.) and the software or computer applications which run on these devices (INE, 2017a)

Furthermore, the interest for spatial inequalities in the provision and use of ICTs dates back to the decade of the eighties. In 1984 the report of the International Telecommunication Union (ITU), an organisation attached to the UN, is published. On this report, the important technological imbalance existing between industrialised countries and developing countries is highlighted (ITU, 2003). Subsequently, it will be in the decade of the nineties of the $20^{\text {th }}$ century, when the researchers will try to explain the difference between having or not having, using or not using computers and internet $(\mathrm{Yu}, 2006)$. It is at that moment when what is known as Digital Divide (DD) appears.

From the first years of the $21^{\text {st }}$ century, the definition of DD provided by the OECD (2001) in the scientific literature is widely accepted (Pick and Azari, 2011; Cilan, et al, 2009). According to this organisation, DD refers to the differences between individuals, families, enterprises and geographic areas at different socio-economic level with regard to their opportunities to access ICTs and to their use of the internet for a wide variety of activities. Consequently, the DD is defined as a multifaceted problem where researchers try to address and identify the reasons causing these disparities.

The importance of detecting, measuring and understanding the DD comes as a result because it can reveal the existing inequalities in the global society of information (Van Dijk, 2006). These technological inequalities and of access to the ICTs directly affect economic growth and the development of the different countries $(\mathrm{Vu}, 2011)$. It was verified that the geographic area, among others, was an important factor in the definition of the DD. This is the reason why, at the end of the last century, the need arises to conduct researches at different spatial scales to assess the provision of infrastructure, the availability and accessibility to computers and the use of the internet (Barzilai-Nahon, 2006; Van Dijk, 2006). These first studies focused mainly on knowing the conditions of access to information by the citizens. The DD was initially understood in a binary way (Cruz-Jesus et al, 2012) and although it was used to describe social and technological inequalities, they were reductive and imprecise analyses.

At present, the pieces of work are focused on measuring and explaining the DD based on the social and demographic factors and the economic characteristics of the users of the ICTS (Vehovar et al, 2006; Barzilai-Nahon, 2006; Mason and Hacker, 2003; Zoroja, 2011), from a wider, and more complex conception and with a multidimensional character (Bose and Luo, 2011; Brown and Russell, 2007; Buyya et al 2009). This has entailed that researches on DD are made from different disciplines (sociology, politics, economy, telecommunication engineering, ...) addressing opportunities of access to ICTs and to the internet by households 
and individuals and, to a lesser extent, the aim of the use and the possibility of a greater or lesser exploitation according to their level of training and knowledge. On the contrary, until now, it is observed a reduced number of research about digital integration of enterprises both for the study of the adoption and use of ICTs in the firms and for the analysis of the DD between them.

In the European context, the EU produced the Digital Agenda (European Commission, 2010; Vicente and López, 2011) with the aim of reducing the DD in Europe. In May 2015, adopted a digital single market strategy (European Commission,2015) as one of its top 10 political priorities. In connection with this, the studies published on ICTs emphasise, above all, the economic effects and the inequalities of use according to countries (Bach, et al., 2013a; Billon et al., 2009) according to factors such as the GDP, the unemployment rate, the sectoral composition, the educational level, the agglomeration economies. The first studies were focused on bringing to light the spatial inequalities in the use of ICTs between the north and south of Europe (Billon et al. 2008), but always in connection with households and the provision of ICT infrastructure (Tranos and Gillespie, 2009).

Furthermore, there are few specific pieces of work in impact journals on the adoption and use of ICTs of enterprises at a regional scale in Europe (Billon et al. 2016; 2017b; Zoroja and Bach, 2016). All this in spite of the implementation of Strategies for Smart Specialisation (RIS3) which consider, as strategic pillar, the applications of ICTs in the economic sectors at regional scale in Europe (Sánchez-Moral, 2015). This shortage is related to the non-publication of data about "ICT usage in enterprises" at a regional scale for Europe (Cruz-Jesus, et al., 2012), unlike what happens with the production of statistics about the "ICT usage in Households and by individuals" of Eurostat and/or the European Commission. As a result, no suitable indexes have been created to measure the level of adoption and use of ICTs by enterprises at a regional level in the European Union.

Therefore, in scientific literature, there are unsolved questions about the level of ICT in the enterprises at a regional scale within the European context. Consequently, this piece of work is focused on the ICT level of enterprises of the Spanish NUTS2 regions to provide answers to: i) Do enterprises in Spanish regions have the same degree of adoption of ICT and e-commerce than those of the European countries?; ii) How profound is the difference in digital development among the Spanish regions and those of European countries at enterprise level?; and iii) Is the DD of the Spanish regions related to a typology of digital development within the European framework? Based on these questions, the main aim of this research is to measure the DD of the Spanish regions at enterprise level within the European context. In order to do so, two specific aims are presented:

a) To know the degree of digital development of the Spanish regions and the European countries at enterprise level. In order to do so, a synthetic index that measures the degree of digital development for European countries is constructed. Subsequently, this index is applied to the Spanish regions to conduct a comparative study. The production of the index entails identifying through factor analysis which variables of the ICTs are key to measuring and characterising the degree of digital development at European level. 
b) To verify if the level of digital development of European countries and Spanish regions at enterprise level is related to differentiated performances. This implies, in the first place, the identification and characterisation of the typology of digital development of the countries through cluster analysis. Afterwards, performing with those groups, a discriminant analysis to classify the Spanish regions within the typology of European countries according to digital development.

To respond to these aims and questions, this piece of work is organised as follows: section 2 will introduce a review of the literature about the measurement of the DD in European enterprises. In section 3 the methodology used to measure and characterise the DD in the enterprises of the Spanish regions based on the European context is described. Section 4 includes the results of the statistical analyses (calculation of the Synthetic, Factor, Cluster and Discriminant index). Section 5 presents the discussion and the conclusions.

\section{THE MEASUREMENT OF THE ENTERPRISE DD IN THE EU}

Authors such as Bach et al (2013b) defend that, although the aims of the Digital Agenda are mainly pointed towards the reduction of the DD between individuals, the EU should also address the promotion of the adoption of ICTs in the enterprises with the aim of shortening the DD between them and improving their capacity of innovation. This author has undertaken a review of the many researches which study the access and use of ICTs of the firms and the existing DD between them. It is highlighted that these studies analyse how size, sector, innovative capacity, etc., of the enterprises influence the implementation of ICTs. In order to do this, simple indicators provided by Eurostat (2017a) and/or the national official statistics are used.

On the other hand, studies about the DD between geographic areas have been addressed at country scale, using synthetic indexes where the measurement of the DD at enterprise level is performed indirectly or with a smaller number of indicators than for the rest of users (individuals, households). Among the most used synthetic indicators, it is worth highlighting: i) "ICT Development Index" of the International Telecommunication Union (ITU, 2017); ii) "Networked Readiness Index" of the World Economic Forum (Dutta and Mia, 2011); and iii) "Knowledge Economy Index" (World Bank, 2012) (Schlichter and Danylchenko, 2014). In some of them, no indicators are included to measure the adoption and use of ICTs in enterprises, as it is the case of the "ICT Development Index". Furthermore, these indexes present a series of limitations: the simplification of complex interrelations between ICTs (Vehovar, et al. 2006); the inadequate selection of variables in ICT technologies ${ }^{1}$; or the random weight which is allocated to each indicator or variable in the calculation of the index (OECD, 2008, Bruno et al., 2010). These restrictions can be corrected with the use of multivariate methods since they are considered the most suitable and reliable to create complex indexes (Vicente-Cuervo and

\footnotetext{
1 The ICT sector is very dynamic, and a lot of technologies have reached a degree of maturity and a high degree of introduction in developed areas (landline telephone, PCs and Internet). Other technologies are emerging and with a less degree of introduction, but they are of better use to measure the level of digital integration of enterprises in developed countries (broadband, internet access in mobile devices, e-invoicing, ICT specialists, etc.).
} 
López-Menéndez, 2006; Cilán 2009 et al, Vicente and López, 2010, Cruz-Jesus et al. 2012). Additionally, they are especially useful for comparisons between countries or geographic areas with similar characteristics (ITU, 2003). The indicators mentioned show the presence of a north- south geographical divide of ICT use at global/worldwide level and between the member states of the EU (Moroz, 2017; Cruz-Jesus et al., 2012; Schlichter and Danylchenko, 2014). In particular, for Europe, a spatial pattern of DD between the north, south and east of Europe is defined (Billon et al., 2009 and 2016).

With the aim of measuring the progress made by European countries in the digitalisation of their economy and society, the European Commission, starting in 2014, publishes annually the results of the Digital Economy and Society Index (DESI). The DESI index includes 30 indicators in five dimensions. The importance attached to each of them is based on the priorities of the digital policy of the European Union and, therefore, the weights are not allocated with a statistical criterion (European Commission, 2017a): 1) Connectivity (25\%); 2) Human Capital (25\%); 3) Use of Internet (15\%); 4) Integration of Digital Technology (20\%); and 5) Digital Public Services (15\%). Within this framework, the classification of use and adoption of ICTs in 2016 is led by Denmark, Sweden, Finland and the Netherlands. The European average of the DESI indicator is 0.52 out of 1 . Spain is slightly above average with 0.54 out of 1 , being on the $14^{\text {th }}$ position. Spain belongs to the group of countries with intermediate results, like Latvia, the Czech Republic, Slovenia, France, Portugal, Lithuania, Malta, Germany and Austria (European Commission, 2017b).

In particular, dimension 4 "Integration of Digital Technology" of the DESI measures the degree of digitisation and use of e-commerce of enterprises on a spatial scale of country. This dimension contains 8 indicators which include 2 sub-dimensions with different weight allocated: a) Business digitization (60\%), which includes: Electronic Information Sharing; RFID; Social Media; e-Invoices; Cloud; and b) SMEs Selling Online (40\%) which incorporates: SMEs Selling Online, Commerce Turnover and Selling Online Cross-border. As with the global index, the weights allocated to each sub-dimension are given according to the priorities of the European digital policy. In this DESI dimension, Denmark obtained the highest score in 2016, followed by Ireland, Sweden and Belgium. Spain is positioned above European average (0.42), in a medium level (position 11 of that ranking), with values above those of the United Kingdom, France or Italy, among other countries. The lowest values correspond to Eastern Europe, being in the last positions Romania, Bulgaria, Poland and Latvia (European Commission, 2017b).

However, as explained in the introduction, the regional studies (NUTS2) in Europe on the level of adoption and use of ICTs in enterprises and, therefore, of the DD are very scarce. In this context, the recent contributions of Billon et al. (2016, 2017a and 2017b) are highlighted. They address, at NUTS1 regional scale, the use of ICTs by households and enterprises providing geographic patterns both of the association between the use of ICTs in households and enterprises in the regions and the relationship between the use of ICTs and regional innovation.

The variables used by these authors to measure the use of ICTs of the enterprises are obtained from the Fifth European Working Conditions Survey, conducted by the European Foundation for the Improvement of Living and Working Conditions (Eurofound, 2012). This survey offers 
information of the countries of the EU-28 on the conditions of the workers of the sector, as well as of the use that they make of computers and internet in the firms. This information is used as indicator of the ICTs of European enterprises (Martin and Omrani 2015). Billon et al. (2016, 2017a and 2017b) point out that only 2 variables can be used to measure the ICTs in the enterprises at NUTS1 scale: "Employees regularly using a computer at work" (percentage of individuals); "Employees regularly using Internet at work" (percentage of individuals). For this last indicator, the authors show: a) the presence of differences in the use of internet by enterprises among European regions (NUTS 1); b) that a clear geographic pattern cannot be identified between north/south and east/west European regions. The highest values of ICT use correspond to southern regions in Spain, France and Greece, while in the United Kingdom, Ireland, Denmark, Germany, the Netherlands and Sweden, the highest values correspond to northern regions. Furthermore, the lowest values can be found in regions of Spain, Portugal, Germany, Poland, Romania and Bulgaria; and c) that the geographic patterns of technology use of enterprises differ from that of the households.

In this context, it is necessary to measure the DD: a) by using a synthetic index on adoption and use of ICTs of the enterprises based on objective criteria using multivariate analysis; $b$ ) at a regional scale (NUTS2), especially for European countries of higher dimensions and less economic weight in Europe, as it is the case of Spain (Cruz-Jesus, et al., 2012).

\section{METHODOLOGY}

\subsection{Unit of analysis, data and variables used}

The unit of analysis of this piece of work are the 28 countries of the EU and also Serbia, the Republic of Macedonia, Norway and Iceland (NUTSO level or country) ${ }^{2}$ and the 17 Spanish regions and the 2 autonomous cities (NUTS2 level or region) (Appendix A1). The analysed variables refer to the use and acquisition of ICTs and e-commerce (Table 1 and Appendix A. 2 and A.4) of the enterprises with more than 10 employees $^{3}$. The unit of measurement of the variables is the percentage of enterprises which have used those ICTs, except for the variable "Persons employed using computers" which is the percentage of total employment (Table 1 ).

\footnotetext{
2 The NUTS classification (Nomenclature of territorial units for statistics) is a hierarchical system for dividing up the economic territory of the EU. Spain is divided into: 7 NUTS 1 (Groups of Autonomous Communities) and 19 NUTS2 (Autonomous Communities and Autonomous Cities). Source: EUROSTAT (2017c) $<$ http://ec.europa.eu/eurostat/documents/345175/7451602/NUTS-map-ES.pdf>

${ }^{3}$ For more information on the metadata of the statistics on ICT usage in enterprises (isoc_e) for European countries, consult the Eurostat page: http://ec.europa.eu/eurostat/cache/metadata/en/isoc_e_esms.htm.
}

For specific questions of each country, see Appendix Reference metadata of ICT usage in Enterpreises (isoc_e) (http://ec.europa.eu/eurostat/cache/metadata/en/isoc_e_esms.htm\#annex1504702344786.

For the statistics published by the Spanish Statistical Office, consult the webpage of Survey on ICT and Electronic Commerce use in Companies: http://www.ine.es/dyngs/INEbase/en/operacion.htm?c=Estadistica_ $\mathrm{C} \& \mathrm{cid}=1254736176743 \&$ menu=metodologia\&idp=1254735576692 and the document Methodological report (http://www.ine.es/en/daco/daco42/comele/metocor_en.pdf). 
Their source is: a) the Community survey on ICT usage and e-commerce in enterprises from Eurostat (2017a, Database) for countries (NUTSO); and, b) the Survey on ICT and e-commerce use in enterprises of the Spanish Statistics Institute (INE, 2017b) for the regions (NUTS2). 13 variables, grouped in 4 components of ICTs, have been selected (Table 1 and Table A.2, Appendix A) with availability of data at both spatial scales of analysis (European countries or NUTSO and Spanish region or NUTS2). The election of these variables is governed by the following criteria:

Table 1. Variables used in the analysis.

\begin{tabular}{|c|c|c|c|}
\hline ICTS COMPONENT & VARIABLE/INDICATOR & MEASURE & SOURCE \\
\hline \multirow{5}{*}{$\begin{array}{c}\text { ICTs and } \\
\text { Connectivity } \\
\text { (Access) to Internet }\end{array}$} & $\begin{array}{l}\text { - Enterprises use DSL or other fixed } \\
\text { broadband connection }\end{array}$ & $\begin{array}{l}\text { Percentage of } \\
\text { enterprises }\end{array}$ & $\begin{array}{l}\text { Eurostat, 2017a } \\
\text { INE, 2017b }\end{array}$ \\
\hline & $\begin{array}{l}\text { - Enterprises connecting to the internet via } \\
\text { a mobile broadband connection }\end{array}$ & $\begin{array}{l}\text { Percentage of } \\
\text { enterprises }\end{array}$ & $\begin{array}{l}\text { Eurostat, 2017a } \\
\text { INE, 2017b }\end{array}$ \\
\hline & $\begin{array}{l}\text { - Enterprises giving portable devices for a } \\
\text { mobile connection to the internet to their } \\
\text { employees }\end{array}$ & $\begin{array}{l}\text { Percentage of } \\
\text { enterprises }\end{array}$ & $\begin{array}{l}\text { Eurostat, 2017a } \\
\text { INE, 2017b }\end{array}$ \\
\hline & - Enterprises that employ ICT specialists & $\begin{array}{l}\text { Percentage of total } \\
\text { employment }\end{array}$ & $\begin{array}{l}\text { Eurostat, } 2017 a \\
\text { INE, 2017b }\end{array}$ \\
\hline & $\begin{array}{l}\text { - Enterprises who have ERP software } \\
\text { package to share information between } \\
\text { different functional areas }\end{array}$ & $\begin{array}{l}\text { Percentage of } \\
\text { enterprises }\end{array}$ & $\begin{array}{l}\text { Eurostat, 2017a } \\
\text { INE, 2017b }\end{array}$ \\
\hline \multirow{5}{*}{ Use of ICTs } & $\begin{array}{l}\text { - Enterprises having a web site or } \\
\text { homepage }\end{array}$ & $\begin{array}{l}\text { Percentage of } \\
\text { enterprises }\end{array}$ & $\begin{array}{l}\text { Eurostat, 2017a } \\
\text { INE, 2017b }\end{array}$ \\
\hline & $\begin{array}{l}\text { - Use social networks (e.g. Facebook, } \\
\text { LinkedIn, Xing, Viadeo, Yammer, etc.) }\end{array}$ & $\begin{array}{l}\text { Percentage of } \\
\text { enterprises }\end{array}$ & $\begin{array}{l}\text { Eurostat, } 2017 a \\
\text { INE, 2017b }\end{array}$ \\
\hline & $\begin{array}{c}\text { - Buy cloud computing services used over } \\
\text { the internet }\end{array}$ & $\begin{array}{l}\text { Percentage of } \\
\text { enterprises }\end{array}$ & $\begin{array}{l}\text { Eurostat, 2017a } \\
\text { INE, 2017b }\end{array}$ \\
\hline & - Persons employed using computers & $\begin{array}{l}\text { Percentage of total } \\
\text { employment }\end{array}$ & $\begin{array}{l}\text { Eurostat, } 2017 a \\
\text { INE, 2017b }\end{array}$ \\
\hline & $\begin{array}{l}\text { - Enterprises that pay to advertise on the } \\
\text { internet }\end{array}$ & $\begin{array}{l}\text { Percentage of } \\
\text { enterprises }\end{array}$ & $\begin{array}{c}\text { Eurostat, 2017a } \\
\text { INE, 2017b }\end{array}$ \\
\hline \multirow{2}{*}{ E-Commerce } & $\begin{array}{c}\text { Enterprises sending e-Invoices B2BG, } \\
\text { suitable for automated processing }\end{array}$ & $\begin{array}{l}\text { Percentage of } \\
\text { enterprises }\end{array}$ & $\begin{array}{l}\text { Eurostat, 2017a } \\
\text { INE, 2017b }\end{array}$ \\
\hline & $\begin{array}{l}\text { - Enterprises receiving e-Invoices, suitable } \\
\text { for automated processing }\end{array}$ & $\begin{array}{l}\text { Percentage of } \\
\text { enterprises }\end{array}$ & $\begin{array}{c}\text { Eurostat, 2017a } \\
\text { INE, 2017b }\end{array}$ \\
\hline E-Government & $\begin{array}{l}\text { - Enterprises sending invoices to other } \\
\text { enterprises or public authorities (B2BG) }\end{array}$ & $\begin{array}{l}\text { Percentage of } \\
\text { enterprises }\end{array}$ & $\begin{array}{c}\text { Eurostat, 2017a } \\
\text { INE, 2017b }\end{array}$ \\
\hline
\end{tabular}

Source: prepared by the authors.

a) Availability of homogeneous data for both spatial scales of analysis (country and region).

Eurostat publishes annually, since 2002, the results of "The Community survey on ICT usage and e-commerce in enterprises". This survey provides data only at country scale and for enterprises with more than 10 employees (provided by the corresponding national statistics institutes), about information and communication technology, the internet, egovernment, e-business and e-commerce in enterprises. On the other hand, the Spanish Statistical Office (INE, 2017b) provides data at regional scale for the Spanish regions (NUTS2) through the "Survey on ICT usage and e-commerce in enterprises" with more than 10 employees. 
b) Availability of homogeneous data for ICT components: provision of ICTs and connectivity to the internet, use of ICTs, e-commerce and e-government.

For the study of ICTs in the European countries and Spanish regions at enterprise level, variables on the most original and/or cutting-edge technologies of ICTs must be included, so that the results are representative to characterise the DD existing nowadays. In fact, Eurostat reassesses annually the statistics of ICTs and reflects the fast pace of technological change. Therefore, the survey on ICT usage in enterprises was initially focused on e-commerce, internet access and the questions of connectivity. However, its scope has been widened subsequently to include a wider variety of topics, such as: cloud computing, ICT specialists and outsourcing of ICT functions (Eurostat, 2017 b; ITU, 2017).

The variables about the "Use of ICTs" refer to the first quarter of 2016 with exceptions for some countries (see Table A.2, Appendix A); while the data on "e-commerce" are from 2015. The studied enterprises belong to the economic sectors of manufacture, construction, trade, transport and other services, according to the Statistical classification of economic activities in the European Community, NACE (Table A.3, Appendix A).

\subsection{Statistical analysis}

In Figure 1, it is graphically summarised the methodology of statistical analysis carried out in this piece of work to measure the level of digital development and characterise the DD of the Spanish regions within the context of the EU.

The analysis procedure is divided into the following stages:

\subsubsection{Stage 1. Construction of a synthetic index of digital development for the analysis of the DD between countries/regions at enterprise level}

To measure the differences in the levels of enterprises digital development of the Spanish regions within the context of the EU countries, a synthetic index is constructed. In the first place, the index for European countries is calculated (European context) and, subsequently, it is applied to Spanish regions to carry out the comparative study (aim a). This index is going to be called Enterprise Digital Development Index (EDDI). Since the variables of adoption and use of ICTs and e-commerce analysed (Table 1) have the same unit of measurement (percentage), the EDDI does not need standardisation and, as a result, the value of EDDI expresses the average percentage of enterprises with more than 10 employees which have adopted and used ICTs and e-commerce in a country/region. In this way, the higher the value of EDDI, the higher the level of enterprise digital development that the country or region will have (higher percentage of enterprises using ICTs and e-commerce). 
Figure 1. Summary of the methodological procedure.

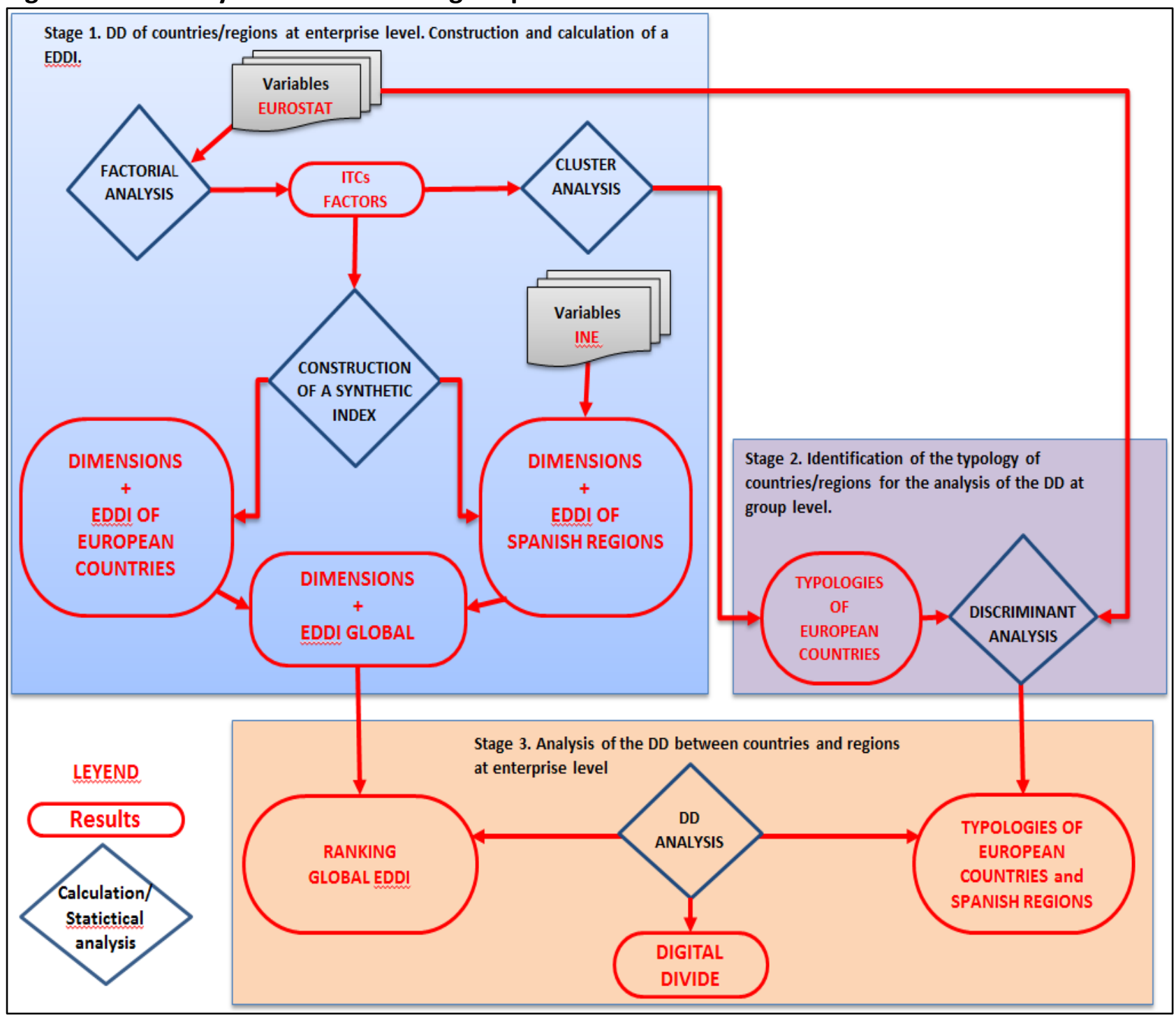

Source: prepared by the authors.

The construction of EDDI follows the methodological contributions of the OECD (2008) and Schuschny and Soto (2009) to elaborate complex and/or synthetic indicators ${ }^{4}$. Generally, when this type of indicators is developed based on multiple variables, no attention is paid to the relationship or underlying structure of the data or to the need that they are categorised or standardised and they can be compared between them. In this context, the cited documents and other authors such as Poza and Fernández (2010), Castro (2009), Castaño (2011), Nunnally (1978), Stapleton (1997) and Nardo et al (2005) recommend using statistical criteria which reflect the underlying relationships between the variables used. One of the most recommended statistical techniques (OECD, 2008; Schuschny and Soto, 2009) is the factor analysis (FA) since it permits:

\footnotetext{
${ }^{4}$ According to the glossary of statistical terms of the OECD (2008), we understand by synthetic indicator that mathematical combination (or aggregation) of the indicators which represent the different components of the concept which is going to be assessed based on a starting system, providing a multidimensional assessment of it (Saisana and Tarantola, 2002).
} 
i) knowing how the variables of digital development that are going to be part of the composite indicator are statistically interrelated. Indeed, the factors of FA show the underlying and latent (not directly observable) dimensions between the variables based on the correlations; and those factors will form the different dimensions of the EDDI.

ii) constructing an indicator according to the relative weight of the variables since they do not have the same importance when defining the level of digital development of enterprises per countries and regions. On the contrary, the analysed variables are grouped in factors according to the value of their correlation with each component. Each factor will add a value in the joint explanation of the phenomenon according to its weight (eigenvalue or total variance explained).

This way, and following a bottom-up procedure, the variables on adoption and use of ICTs and e-commerce of the enterprises will be grouped forming different factors. Each factor will be a dimension according to its weight in the factor model which explains a part of the level of digital performance of the enterprises of each country and region. Finally, all dimensions will be added to form the EDDI of each country and region through the calculation of the weighted arithmetic mean according to the weight of each dimension (the value of the variance explained by each factor). All this can be summarised in the following equation:

Where:

$$
\text { EDDI }=\sum_{f=1}^{n}\left(A_{f} D_{f i}\right) / n
$$

\begin{tabular}{|c|c|c|}
\hline EDDI & \multicolumn{2}{|c|}{ Enterprise Digital Development Index of each country and/or region } \\
\hline $\mathrm{Af}_{1}$ & \multicolumn{2}{|c|}{ Weight of each dimension (eigenvalue of each factor in a country/region) } \\
\hline$D_{f 1}$ & \multicolumn{2}{|c|}{ Value of each dimension (\% of enterprises of each in a country/region) } \\
\hline & \multicolumn{2}{|c|}{ Number of dimensions (factors) } \\
\hline & \multicolumn{2}{|c|}{$D_{f i}=\left(c_{f 1} * V_{1}\right)+\left(c_{f 2} * V_{2}\right)+\left(c_{f 3} * V_{3}\right) \ldots\left(c_{f i} * V_{i}\right)+$ Rest $f_{i}$} \\
\hline & $\mathrm{C}_{\mathrm{fi}}$ & $\begin{array}{l}\text { The factor loading for each variable included in the factor } \\
\text { (Table 2. Rotated component matrix). }\end{array}$ \\
\hline & $\mathrm{V}_{\mathrm{i}}$ & $\begin{array}{l}\text { The value of each variable of ICTs (in \% of enterprises) for each } \\
\text { country/region. }\end{array}$ \\
\hline & Rest of $f_{i}$ & $\begin{array}{l}\text { The addition of the factor loadings of the variables which } \\
\text { are not a part of the factor model found. }\end{array}$ \\
\hline
\end{tabular}

\subsubsection{Stage 2. Identification of the typology of countries/regions for the analysis of the DD at group level}

The aim of this stage is to know if the DD between the Spanish regions and the European countries is related to a similar performance (typology) of EDDI. Consequently, this analysis involves knowing to which typology of EDDI of European countries belong the Spanish regions. This entails: 
a) Identifying how many typologies of European countries there are and which variables define the characteristics of these clusters through cluster analysis in two stages (hierarchical cluster analysis and the K-means analysis).

b) Classifying the Spanish regions in the clusters of European countries by using discriminant analysis. The discriminant analysis is a statistical multivariate technique which: i) provides classification procedures of new observations of unknown origin in a series of groups known beforehand by using discriminant equations-functions; and ii) permits knowing which variables on the use of ICTs and e-commerce in European enterprises have a greater discriminatory and predictive power in the classification and, therefore, contribute, to a larger extent, to the explanation of the differences of DD between the groups of countries and the regions.

\section{RESULTS}

\subsection{The EDDI and its dimensions. Analysis of the DD between countries and regions at enterprise level}

\subsubsection{Key variables and production of the EDDI at European level}

The EDDI is calculated based on the variables of use and adoption of ICTs and e-commerce (Table 1) of the enterprises of European countries (European level), through exploratory factor analysis. This procedure was carried out with the programme IBM SPSS v.24. The 13 original variables were introduced and the extraction method of the principal components analysis and Varimax rotation with Kaiser standardisation was used. The results (Appendix B) offered 3 factors of adoption and use of ICTs and e-commerce in the European enterprises based on 11 very interrelated variables (Table 2). The 3 factors explain the $79.2 \%$ of total variance, with a resulting KMO of 0.74 and the determinant equal to $1.41 \mathrm{E}-019$.

Therefore, the digital development of European countries enterprises is defined by:

- Factor 1. It provides $50.2 \%$ of the variance. It is formed by 4 variables related to the provision in ICTs and connectivity: "Enterprises use DSL fixed broadband connection"; "Enterprises connecting to the internet via a mobile broadband connection"; "Enterprises giving portable devices for a mobile connection to the internet to their employees"; and "Enterprises having a web site or homepage". They are ICTs of a high technological complexity such as "DSL or other fixed broadband connection" which is a dynamic system for the transmission of information, applications and advanced electronic services at high speed (Cimoli and Correa, 2010).

- Factor 2. It represents almost $17.0 \%$ of the variance and links 3 variables: "Enterprises receiving e-Invoices, suitable for automated processing"; "Enterprises sending eInvoices B2BG, suitable for automated processing"; and "Buy cloud computing services used over the internet". This factor explains that European enterprises with more than 10 employees still have not reached a high level of digital development for e-commerce. 
- Factor 3. It represents $12.1 \%$ of the total variance explained and it is related to 4 variables which present different signs in their correlation with this component. With positive correlation, they are: "Enterprises that employ ICT specialists"; "Use social networks (e.g. Facebook, LinkedIn, Xing, Viadeo, Yammer, etc)"; and "Persons using computers in the enterprise. While the variable: "Enterprises sending invoices to other enterprises or public authorities (B2BG)" has a correlation in the negative sense. This component highlights that those enterprises with availability and use of ICT specialists and of staff with computers are present in social networks. However, on the contrary, they are not characterised by their interaction with the public authorities and other enterprises by electronic means.

When presenting variables with inverse correlations, this factor can indicate three possible situations: i) In the case that the factor has a positive value, it indicates that European enterprises having a high percentage in the 3 first variables (specialists, staff with computers and presence in social networks) and a low value in the last variable (enterprises which are in contact with the public authorities and other enterprises). ii) When the factor presents a negative value, it means the opposite: that there are a high percentage of European enterprises that "interact with the public authorities and other enterprises", and a low proportion of firms which use ICT specialists, employees with computers and which participate in social networks. iii) Last, if the values of this factor are around 0 , it means that European enterprises present percentages around the average (of little significance) in all the variables (in the use of specialists, staff with computers, presence in social networks and interaction through electronic means with the public authorities and other enterprises).

Table 2. Rotated component matrix

\begin{tabular}{lcc}
\hline \multicolumn{1}{c}{ Variables ICTs } & Factors \\
\cline { 2 - 2 } Enterprises use DSL or other fixed broadband connection & 1 & 2 \\
Enterprises connecting to the internet via a mobile broadband connection & 0.88 \\
Enterprises giving portable devices for a mobile connection to the internet to their & 0.85 \\
$\quad$ employees & 0.78 \\
Enterprises having a web site or homepage & 0.77 \\
Enterprises receiving e-Invoices. suitable for automated processing & 0.89 \\
Enterprises sending e-Invoices B2BG. suitable for automated processing & 0.73 \\
Buy cloud computing services used over the internet & 0.64 \\
Enterprises that employ ICT specialists & \\
Use social networks & 0.77 \\
Persons employed using computers in the enterprise & 0.73 \\
Enterprises sending invoices to other enterprises or public authorities (B2BG) & 0.65 \\
\hline
\end{tabular}

Extraction method: principal components analysis.

Rotation method: Varimax with Kaiser standardisation. The rotation has converged in 6 iterations.

According to these 3 components of the factor model, EDDI, which would be formed by 3 dimensions (Figure 2), is constructed.

- Dimension 1. It is formed by factor 1. We could call this dimension "Provision and connectivity of fundamental ICTs of advanced character". This first component of EDDI shows that the digital development of enterprises with more than 10 
employees in Europe and, therefore, the differences between countries at level of digital integration of enterprises, is based on the provision of fundamental ICTs (such as internet access or availability of mobiles) but with advanced character (broadband) (Spurge and Roberts, 2005).

Figure 2. Factor model for the creation of EDDI and its dimensions

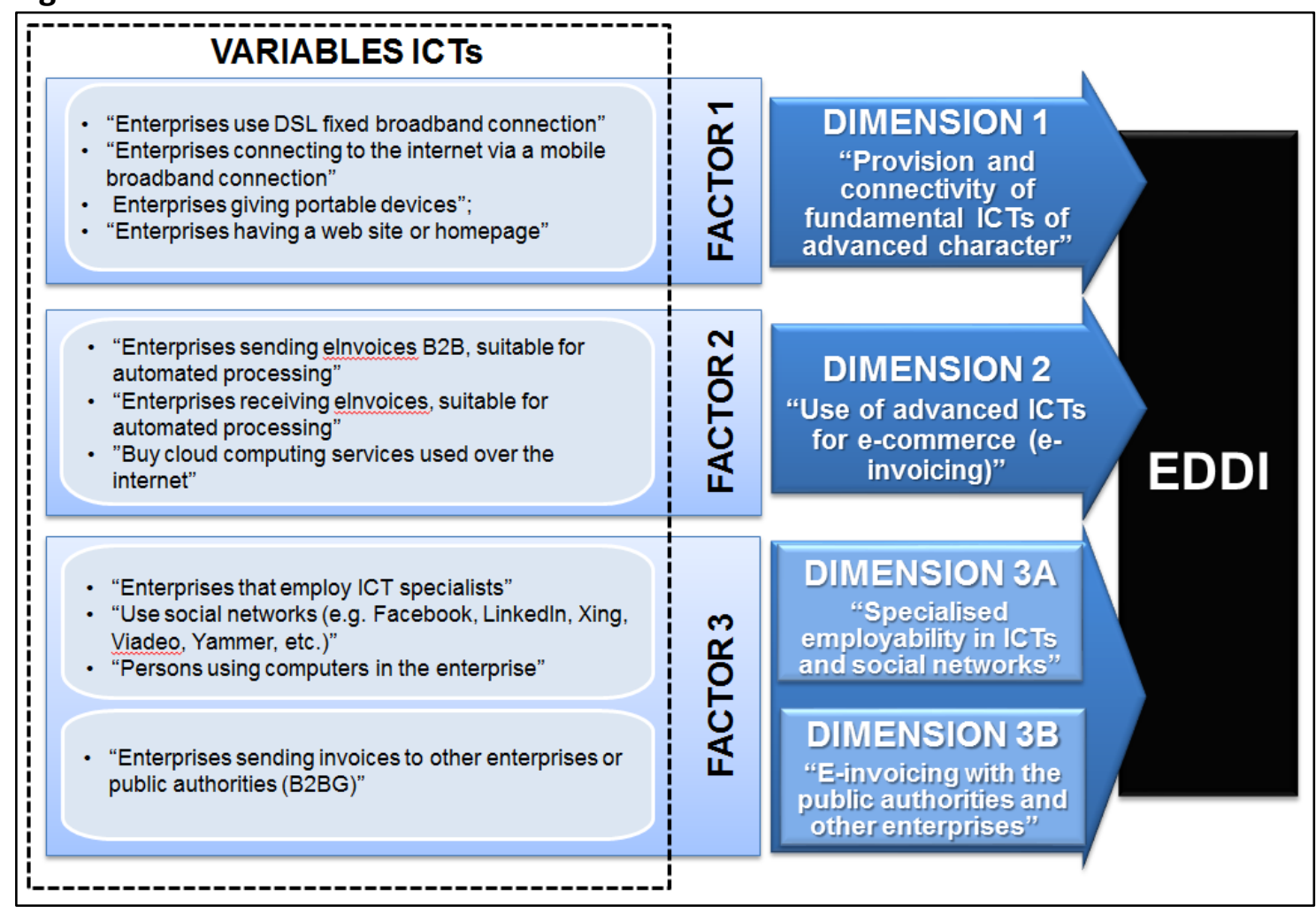

Source: prepared by the authors.

- Dimension 2. It is composed by the second factor and it is called "Use of advanced ICTs for e-commerce (e-invoicing)". This component of EDDI indicates that the practice of e-commerce in enterprises of European countries is related to the use of advanced ICTs based on networking, such as cloud computing, which permit the flow and access to shared information from different places and devices, as well as the integration of interorganisational information systems (Soliman and Youssef, 2003).

- Dimension 3. Factor 3 presents a double meaning according to the positive or negative sign which show the variables correlated with it. This implies that this dimension of EDDI is divided into two sub-dimensions:

- Dimension 3A. It is linked to the variables with positive correlation in this third factor and it would be called "Specialised employability in ICTs and social networks". The use of social networks is related to the use that enterprises of European countries make of more sophisticated ICTs, which, furthermore, require a greater effort in staff training (Rovira et al, 2013).

- Dimension 3B. This component is related to the variable which has negative correlation in the third factor. It is called "E-invoicing with the public 
authorities and other enterprises". The establishment of the e-invoice by enterprises of European countries is mainly related to the commercial activity of enterprises and the administrative procedures with the public authorities. Its introduction is subject to legal requirements by the tax authorities of each country (Hernández-Ortega and Serrano-Cinca, 2009; Bartholomew, 2005).

These 3 dimensions together are going to characterise the global enterprises digital development of European countries. According to the FA, these dimensions do not have the same weight in the calculation of EDDI, but they differ in importance according to the eigenvalue (or total variance explained) of their factor (Table 3). Therefore, according to the value of these weights, the equation [1] for the calculation of EDDI would have the following mathematical expression:

$$
\operatorname{EDDI}(\%)=(63.4 * \mathrm{D} 1+21.4 * \mathrm{D} 2+15.2 * \mathrm{D} 3) / 3
$$

while the equation [2] would be expressed like this:

(D1) Dimension $1=(0.881 * \%$ Enterprises use DSL or other fixed broadband connection $)+(0.845 * \%$ Enterprises connecting to the internet via a mobile broadband connection $)+(0.778 * \%$ Enterprises giving portable devices for a mobile connection $)+(0.766 * \%$ Enterprises having a web site or homepage) + Rest fi

The other two dimensions would be calculated the same way.

\subsubsection{Analysis of the DD between countries and regions measured by EDDI}

The calculation of the EDDI of the Spanish regions has been done following the methodology indicated in Table 3, with the variables of ICTs of the "Survey on ICT and e-commerce use in enterprises", of the Spanish Statistical Office (INE, 2017b). As a result, the EDDI is obtained for each region from the equations [3] and [4]. With the EDDI of the countries and regions, and the 3 dimensions, a ranking of digital development at enterprise level is generated (Table 4).

The main results that can be obtained from this ranking are that enterprises with more than 10 employees of the Spanish regions are at a medium or higher level of digital development than their counterparts in European countries. Furthermore, they show a lower DD between them, with regards to what happens in European countries.

Indeed, according to EDDI, $56.2 \%$ of enterprises of Spanish regions have incorporated ICTs, while in the European countries they only reach $52.3 \%$ (Table 3). On the other hand, $79 \%$ of Spanish regions (except Cantabria, Canarias, Castilla-La Mancha and Melilla) have an EDDI above average of Spanish regions, along with the European countries of Finland, Denmark, Sweden, Norway, Slovenia, Netherlands, Iceland and Belgium. Madrid and Cataluña are the first Spanish regions, being in the fifth and sixth position of the EDDI ranking (Table 4). There are only two countries, Finland and Denmark, which have a higher percentage of enterprise 
digital development than Spanish regions both in the global EDDI and on its different dimensions.

Table 3. Elaboration of the Enterprise Digital Development Index (EDDI).

\begin{tabular}{|c|c|c|c|c|c|}
\hline \multicolumn{4}{|c|}{ FACTORIAL MODEL } & \multicolumn{2}{|c|}{ INDEX CONSTRUCTION } \\
\hline VARIABLES & $\begin{array}{l}\text { WEIGHING } \\
\text { (correlations in } \\
\text { the rotated } \\
\text { component } \\
\text { matrix) }\end{array}$ & FACTORS & $\begin{array}{c}\text { WEIGHT } \\
\% \text { total } \\
\text { variance } \\
\text { explained } \\
\text { (over 100) } \\
\end{array}$ & DIMENSIONS & \\
\hline $\begin{array}{l}\text { - Fixed broadband } \\
\text { - Mobile broadband } \\
\text { - Portable devices } \\
\text { - Web site or homepage }\end{array}$ & $\begin{array}{l}0.881 \\
0.845 \\
0.778 \\
0.766\end{array}$ & FACTOR 1 & 63.4 & $\begin{array}{c}\text { D1 } \\
\text { Provision and } \\
\text { connectivity of } \\
\text { fundamental ICTs of } \\
\text { advanced character }\end{array}$ & \\
\hline $\begin{array}{l}\text { - Receiving e-invoices } \\
\text { - Sending e-invoices } \\
\text { B2BG } \\
\text { - Buy Cloud computing } \\
\text { - ICT specialists } \\
\text { - Use social networks } \\
\text { - Persons using } \\
\text { computers } \\
\text { - Sending invoices to } \\
\text { other enterprises or } \\
\text { public authorities }\end{array}$ & $\begin{array}{l}0.885 \\
0.735 \\
0.639\end{array}$ & FACTOR 2 & 15.2 & $\begin{array}{c}\text { D2 } \\
\text { Use of advanced ICTs } \\
\text { for e-commerce (e- } \\
\text { invoicing) } \\
\text { D3 } \\
\text { D3A. Specialised } \\
\text { employability in ICTs } \\
\text { and social networks } \\
\text { D3B. E-invoicing } \\
\text { with the public } \\
\text { authorities and } \\
\text { other enterprises. }\end{array}$ & EDDI \\
\hline
\end{tabular}

Source: prepared by the authors

Table 4. Ranking of European countries and Spanish regions according to EDDI (in average $\%$ of enterprises with more than 10 employees).

\begin{tabular}{|c|c|c|c|c|c|c|}
\hline \multirow{2}{*}{ Countries/Regions } & \multirow{2}{*}{$\begin{array}{c}\text { Spatial } \\
\text { Level }\end{array}$} & \multicolumn{4}{|c|}{ Dimensions } & \multirow{2}{*}{ EDDI } \\
\hline & & D1 & D2 & D3A & D3B & \\
\hline Finland & NUTSO & 77.7 & 50.4 & 36.5 & 58.8 & 70.1 \\
\hline Denmark & NUTSO & 75.9 & 34.6 & 36.9 & 58.2 & 65.5 \\
\hline Sweden & NUTSO & 72.4 & 27.4 & 33.6 & 54.4 & 61.0 \\
\hline Norway & NUTSO & 66.4 & 38.3 & 37.2 & 55.0 & 60.2 \\
\hline Madrid. Comunidad de & NUTS2 & 74.0 & 15.2 & 34.6 & 58.4 & 59.9 \\
\hline Cataluña & NUTS2 & 73.4 & 14.4 & 33.3 & 57.5 & 59.1 \\
\hline Slovenia & NUTSO & 69.4 & 27.5 & 27.5 & 61.9 & 58.7 \\
\hline Aragón & NUTS2 & 74.6 & 10.3 & 26.8 & 56.3 & $\mathbf{5 7 . 9}$ \\
\hline País Vasco & NUTS2 & 73.6 & 11.0 & 29.1 & 56.1 & $\mathbf{5 7 . 7}$ \\
\hline Netherlands & NUTSO & 67.3 & 23.9 & 36.5 & 54.4 & 57.4 \\
\hline Navarra. Comunidad Foral de & NUTS2 & 73.3 & 8.5 & 26.9 & 58.4 & 56.8 \\
\hline Comunitat Valenciana & NUTS2 & 72.4 & 10.2 & 29.2 & 56.1 & 56.8 \\
\hline Iceland & NUTSO & 68.2 & 23.2 & 42.1 & 28.1 & 56.7 \\
\hline Asturias. Principado de & NUTS2 & 73.1 & 9.5 & 25.5 & 56.1 & 56.5 \\
\hline Rioja. La & NUTS2 & 71.0 & 14.4 & 25.9 & 58.9 & 56.5 \\
\hline Belgium & NUTSO & 67.9 & 22.6 & 32.7 & 46.9 & 56.4 \\
\hline Extremadura & NUTS2 & 71.6 & 12.3 & 25.7 & 57.8 & 56.3 \\
\hline Spain & NUTSO & 71.4 & 12.1 & 26.3 & 56.8 & 56.2 \\
\hline Andalucía & NUTS2 & 70.8 & 11.1 & 27.6 & 58.4 & 55.9 \\
\hline Galicia & NUTS2 & 71.7 & 11.2 & 24.6 & 55.5 & 55.8 \\
\hline
\end{tabular}




\begin{tabular}{|c|c|c|c|c|c|c|}
\hline Balears. Illes & NUTS2 & 70.0 & 13.2 & 28.8 & 54.7 & 55.8 \\
\hline Ceuta & NUTS2 & 71.3 & 16.8 & 16.6 & 55.5 & 55.5 \\
\hline Murcia. Región de & NUTS2 & 70.7 & 10.7 & 25.7 & 58.1 & 55.4 \\
\hline Castilla y León & NUTS2 & 71.4 & 11.7 & 22.9 & 54.5 & 55.4 \\
\hline Malta & NUTSO & 67.1 & 17.0 & 34.9 & 51.3 & 55.4 \\
\hline Austria & NUTSO & 68.0 & 15.9 & 29.3 & 57.5 & 55.3 \\
\hline Cantabria & NUTS2 & 69.7 & 11.0 & 25.5 & 55.5 & 54.6 \\
\hline Canarias & NUTS2 & 68.5 & 13.2 & 26.5 & 56.8 & 54.6 \\
\hline Castilla-La Mancha & NUTS2 & 69.3 & 13.0 & 22.8 & 55.7 & 54.4 \\
\hline Lithuania & NUTSO & 66.6 & 21.3 & 23.3 & 50.0 & 54.1 \\
\hline Estonia & NUTSO & 65.9 & 19.9 & 23.0 & 56.3 & 53.8 \\
\hline Ireland & NUTSO & 63.9 & 19.9 & 37.1 & 33.1 & 52.9 \\
\hline United Kingdom & NUTSO & 64.2 & 14.0 & 33.0 & 49.4 & 52.4 \\
\hline Luxembourg & NUTSO & 66.0 & 12.0 & 29.2 & 46.9 & 52.4 \\
\hline Czech Republic & NUTSO & 68.3 & 12.0 & 22.6 & 40.6 & 52.4 \\
\hline Melilla & NUTS2 & 66.1 & 11.6 & 22.7 & 57.9 & 52.2 \\
\hline Germany & NUTSO & 64.5 & 14.7 & 29.1 & 46.3 & 52.0 \\
\hline Croatia & NUTSO & 65.2 & 12.7 & 24.4 & 49.4 & 51.5 \\
\hline Portugal & NUTSO & 61.3 & 20.6 & 24.4 & 45.0 & 50.4 \\
\hline Slovakia & NUTSO & 61.2 & 18.4 & 23.0 & 53.2 & 50.3 \\
\hline France & NUTSO & 60.6 & 17.0 & 25.8 & 47.5 & 49.6 \\
\hline Italy & NUTSO & 60.0 & 17.9 & 23.7 & 49.7 & 49.3 \\
\hline Cyprus & NUTSO & 60.3 & 8.8 & 32.3 & 53.8 & 49.1 \\
\hline Serbia & NUTSO & 64.7 & 3.9 & 22.0 & 49.7 & 48.9 \\
\hline Hungary & NUTSO & 59.8 & 13.4 & 24.4 & 53.2 & 48.5 \\
\hline Latvia & NUTSO & 57.8 & 19.9 & 16.7 & 60.0 & 48.0 \\
\hline Poland & NUTSO & 58.4 & 15.2 & 18.2 & 58.2 & 47.4 \\
\hline Republic of Macedonia & NUTSO & 58.6 & 9.4 & 23.4 & 48.2 & 46.4 \\
\hline Greece & NUTSO & 50.6 & 9.4 & 27.2 & 35.0 & 40.9 \\
\hline Bulgaria & NUTSO & 42.3 & 17.5 & 19.2 & 43.8 & 36.8 \\
\hline Romania & NUTSO & 43.1 & 7.2 & 17.0 & 44.4 & 34.8 \\
\hline Average NUTSO & & 63.6 & 18.7 & 27.9 & 49.9 & 52.3 \\
\hline Average NUTS2 & & 71.4 & 12.1 & 26.3 & 56.8 & 56.2 \\
\hline Average Global & & 66.5 & 16.2 & 27.3 & 52.5 & 53.8 \\
\hline
\end{tabular}

As can be seen in Map 1, the differences of DD between regions and countries are significant and they show two different situations. On the one hand, Spanish regions have a small DD, which means that they present values of similar digital development in their enterprises (only 7.7\% between the region with the highest and lowest EDDI, with an average divide of $3.72 \%$ among regions). On the other hand, among European countries, the DD is high. The country with the highest EDDI doubles the value of the country with the lowest EDDI, with a DD of $35.2 \%$. The average difference among countries is of 17.7 percentage points, five times more than the DD between regions. The Spanish regions are close between them (similar values, except for Melilla, with the lowest EDDI) with small dispersion (1.7\% of typical deviation and $3.1 \%$ of coefficient of variation); European countries show a high dispersion (7.5\% and $13.7 \%$ ) as result of their big differences in the DD (Graph 1). 
Map 1. EDDI per countries and regions (in average \% of enterprises).

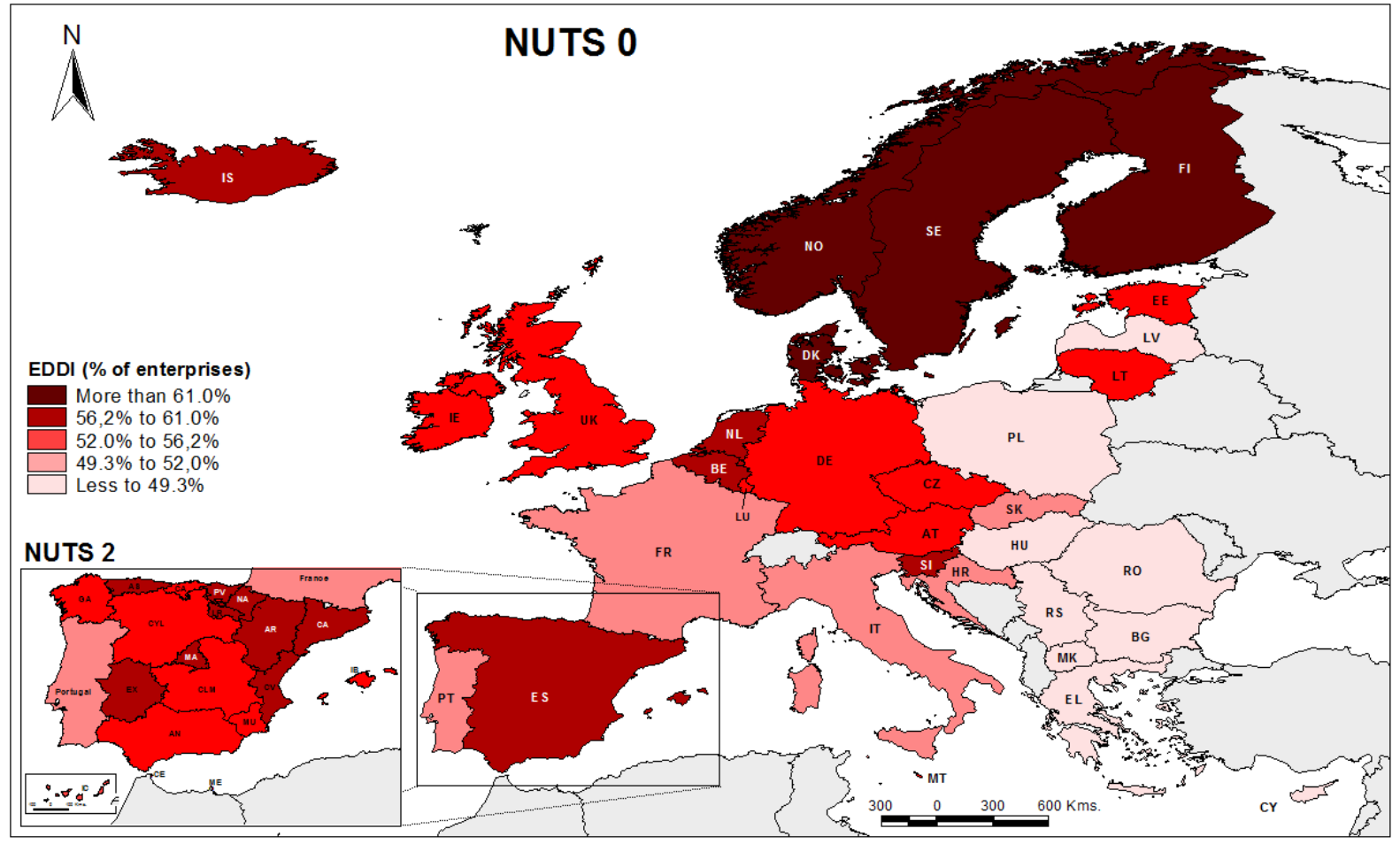

Source: prepared by the authors.

Graph 1. EDDI ranking (\% enterprises) per European countries (NUTSO) and Spanish regions (NUTS2).

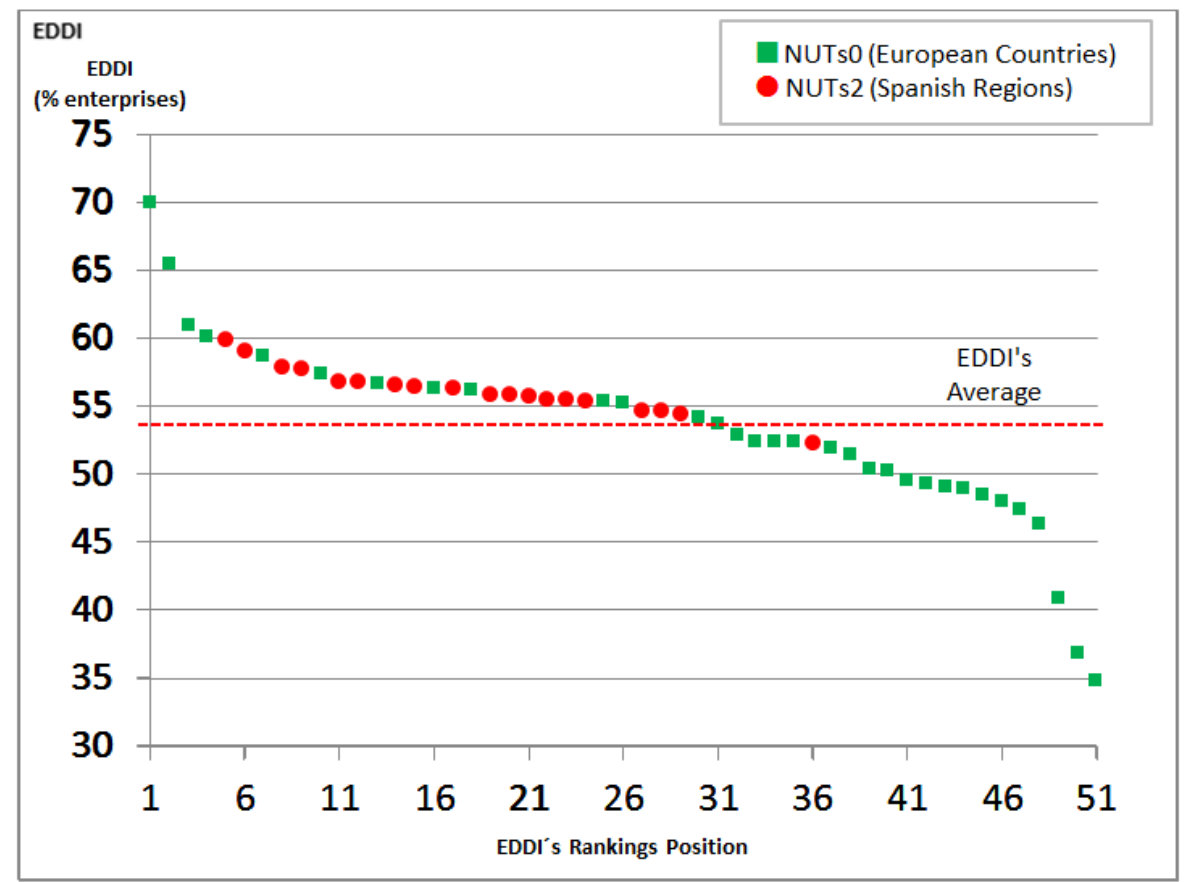

Source: prepared by the authors

If the values of the different dimensions of EDDI are analysed (Table 4), a differentiated performance is also seen between the Spanish regions and the European countries. This way, in Dimension 1, "Provision and Connectivity of fundamental ICTs of advanced character", the NUTS2 have higher percentages of enterprises than NUTSO. The difference between the 
average percentage of the regional enterprises and that of the countries is of almost 8 points (71.4\% and $63.6 \%$, respectively). It is the most developed digital dimension and where Spanish enterprises stand out the most and, except for Melilla, all the others are above average in this dimension (66.5\%). In fact, Aragón is the third in the EDDI ranking with the highest percentage of enterprises with "Supply and Connectivity of fundamental ICTs of advanced character", after Finland and Denmark. 7 Spanish regions can be found within the ten first positions of this dimension.

Graph 2. Relation between EDDI and its dimensions per countries and regions.
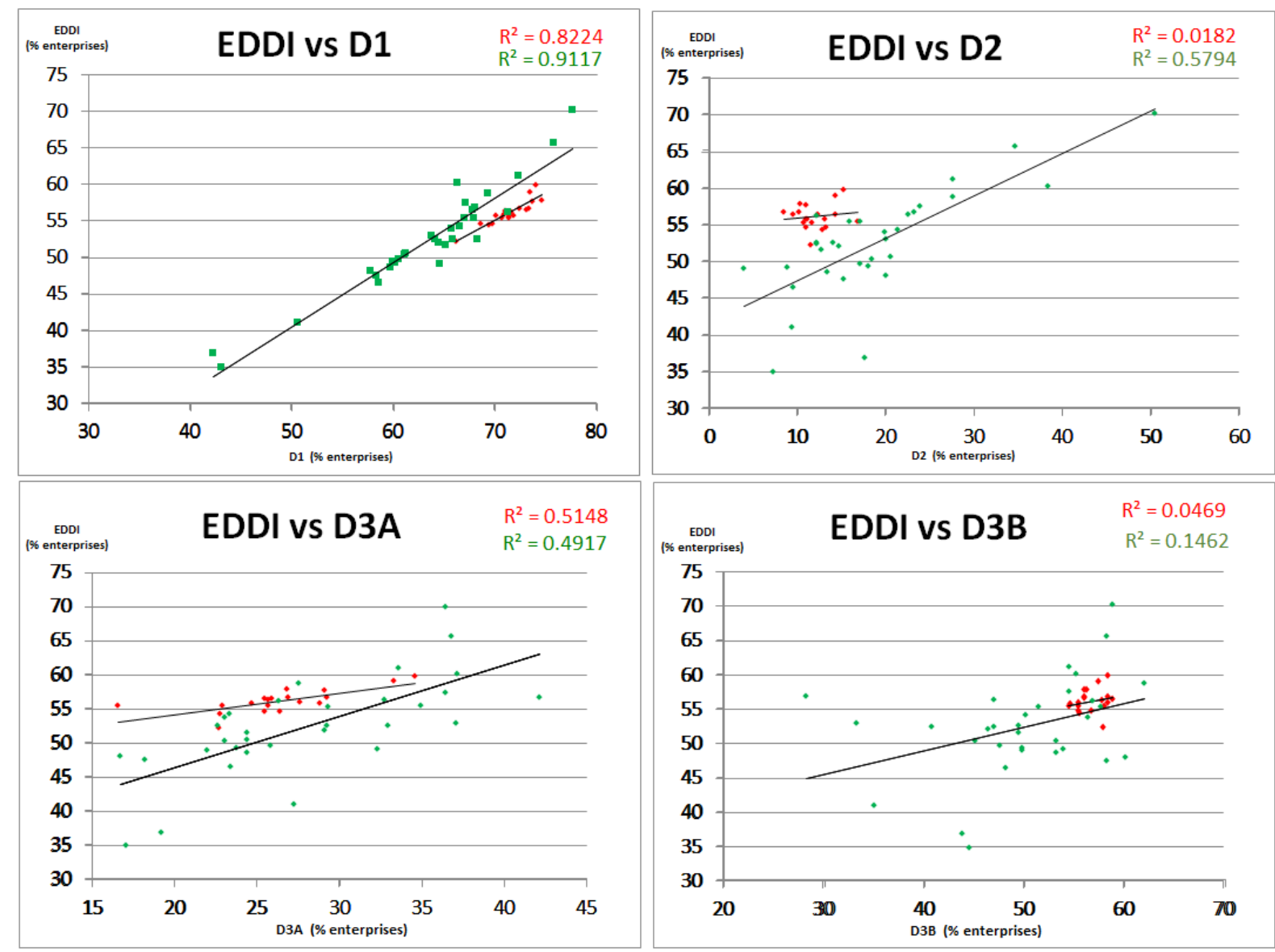

nUTSO / Countries NUTS2 / Regions

Source: prepared by the authors

The analysis of the correlation between each dimension and the EDDI has been measured through the $R^{2}$ coefficient with the data of table 4 . Graph 2 shows in 4 figures the differentiated performance of the regions and countries in each of the dimensions of EDDI. Dimension 1, "Provision and Connectivity of fundamental ICTs of advanced character", is the one with the biggest influence on the EDDI (it presents the highest value of the $\mathrm{R}^{2}$ coefficient) both for countries and for regions. This shows that the biggest part of digital development of the firms of regions and countries is supported by Dimension 1. That influence is bigger for the digital development of the enterprises of countries than for those of the regions ( 0.91 and 0.82 of $R^{2}$, respectively). However, the DD in this dimension is much lower in NUTS2 than in NUTSO. In this case, regions have similar and high values (with big concentration and a 
coefficient of variation of $3 \%$, as observed in the figures of graph 2), while countries show very extreme data (high dispersion and coefficient of variation of $12.1 \%$ ).

The Spanish regions surpass the Europeans countries in digital development at enterprise level also in the dimension 3B "Electronic interaction with the public authorities and other enterprises" (56.8\% of NUTS2 for $49.9 \%$ of NUTSO). As it happened with Dimension 1, Graph 2 displays a differentiated performance of DD between both spatial scales. Once again Spanish regions have a smaller divide (with a range of $4.3 \%$ and a coefficient of variation of 2.4\%); while European countries show big differences in this dimension (wide dispersion, a range of $37.8 \%$ and a coefficient of variation of $15.7 \%)$.

Opposite to the two previous dimensions, European countries have a higher percentage of enterprises with integration of ICTs than Spanish regions in D2 and D3A. The biggest contrast is found regarding the "Use of advanced ICTs for e-commerce" (Dimension 2). The difference between the percentage of European and Spanish enterprises is of $6.6 \%$ (18.7\% and $12.1 \%$, respectively). It is clearly the largest deficit of digital development of the enterprises of the Spanish regions, which entails that this dimension contributes little to the digital development of Spanish enterprises ( $a R^{2}$ of only 0.02 ). It is totally the opposite in European countries (with a $\mathrm{R}^{2}$ of almost 0.6 ), on which the "Use of advanced ICTs for e-commerce" is the second distinctive characteristic of digital development of their enterprises, after the first dimension. The only Spanish region in the ranking, with values above European average $(16.2 \%$ of enterprises) is Ceuta, in position 19.

In terms of DD, Dimension 2 shows the biggest contrasts among enterprises in Spain, in Europe and between both. The regions and countries present a coefficient of variation and the highest DD of all dimensions (17.3\% and $8.3 \%$, respectively). In European countries, the DD in this dimension gets bigger (up to $46.5 \%$ ), with the most uneven values of all, due to a dispersion of $31 \%$ on average (typical deviation) and, above all, to a coefficient of variation which reaches $50.5 \%$.

On the contrary, Dimension 3A, "Specialised employability in ICTs and social networks" is the characteristic of digital development with the greatest similarity between countries and regions. The difference of percentage of enterprises between both is small, $27.9 \%$ for European countries and $26.3 \%$ for Spanish regions. This similarity can also be seen in Graph 2 , with similar values: i) in the weight that this dimension provides to the global EDDI (similar regression lines and of $\mathrm{R}^{2}$ ); ii) in the $\mathrm{DD}$, which is higher among countries (25.4\%) than among regions (18\%); and iii) in the dispersion (differentiation) among individuals (with a coefficient of variation of $24 \%$ for countries and $15 \%$ for regions).

\subsection{Typologies of European countries and Spanish regions according to enterprise digital development}

\subsubsection{Identification of a typology of enterprise digital development of European countries}

The dendrogram obtained by using the Ward's method with the squared Euclidean distance (Table C.1, Appendix C) shows 6 differentiated groups of European countries based on the 3 dimensions. With the K-means analysis, the values that define the characteristics of each of 
the 6 clusters were obtained (see Table 5). Each cluster groups of European countries which similar percentages of enterprises in the 3 dimensions of EDDI. The values of the centroids of each cluster permit establishing a hierarchy between them according to the digital inclusion of enterprises. Therefore, clusters with a higher percentage of enterprises in the 3 dimensions are considered to have a bigger inclusion or enterprise digital development (and the opposite). Consequently, the 6 clusters of countries are organised from higher to lower percentage of inclusion or enterprise digital development in the following way:

Table 5. Characteristics of clusters by dimensions and assigned countries (\% of enterprises).

\begin{tabular}{|c|c|c|c|c|c|c|}
\hline CLUSTER & 1 & 2 & 3 & 4 & 5 & 6 \\
\hline Dimension 1 & 73,1 & 70,0 & 68,4 & 64,7 & 60,8 & 45,3 \\
\hline Dimension 2 & 37,7 & 16,1 & 13,7 & 15,6 & 8,9 & 11,4 \\
\hline Dimension $3 \mathrm{~A}$ & 36,0 & 30,2 & 27,1 & 22,6 & 25,5 & 21,1 \\
\hline Dimension 3B & 56,6 & 54,5 & 50,4 & 53,9 & 51,2 & 41,1 \\
\hline & & & $\begin{array}{c}\text { Croatia } \\
\text { Czech Republic }\end{array}$ & & & \\
\hline COUNTRIES & $\begin{array}{l}\text { Denmark } \\
\text { Finland } \\
\text { Norway } \\
\text { Sweden }\end{array}$ & $\begin{array}{l}\text { Austria } \\
\text { Belgium } \\
\text { Iceland } \\
\text { Malta } \\
\text { Netherlands } \\
\text { Slovenia }\end{array}$ & $\begin{array}{l}\text { Estonia } \\
\text { Germany } \\
\text { Ireland } \\
\text { Luxembourg } \\
\text { Lithuania } \\
\text { Spain } \\
\text { United Kingdom }\end{array}$ & $\begin{array}{l}\text { France } \\
\text { Italy } \\
\text { Latvia } \\
\text { Poland } \\
\text { Portugal } \\
\text { Slovakia }\end{array}$ & $\begin{array}{l}\text { Cyprus } \\
\text { R. of Macedonia } \\
\text { Hungary Serbia }\end{array}$ & $\begin{array}{l}\text { Bulgaria } \\
\text { Greece } \\
\text { Romania } \\
\text { Turkey }\end{array}$ \\
\hline
\end{tabular}

Source: prepared by the authors.

- Cluster 1: Countries with very high digital inclusion of enterprises and "Use of Advanced ICTs for e-commerce (e-invoicing)". It is the group of countries which present the highest percentages of enterprises with digital development in the 3 dimensions. It is composed of 4 countries (Denmark, Finland, Norway and Sweden) whose enterprises present values above average and the rest of countries, especially highlighting D2 "Use of advanced ICTs for e-commerce" (in more than $37.7 \%$ of enterprises); D3A "Specialised employability in ICTs and social networks" (in 36.0\% of firms); and D1 "Provision and connectivity of fundamental ICTs of advanced character" (in more than $73 \%$ of enterprises).

- Cluster 2: Countries with high digital inclusion of enterprises and "Specialised employability in ICTs and social networks". This cluster comprises 6 countries: Austria, Belgium, Iceland, Malta, the Netherlands and Slovenia. These countries are characterised for having in all dimensions the highest percentages of enterprises which have implemented ICTs after Cluster 1. The most outstanding characteristics of these countries are D3A "Specialised employability in ICTs and social networks" (in 30.2\% of enterprises); and D1 "Provision and connectivity of fundamental ICTs of advanced character" (in 70\% of firms).

- Cluster 3. Countries with intermediate digital inclusion with low use of "Specialised employability in ICTs and social networks". It is the largest group, composed of 9 countries (Croatia, Luxembourg, Germany, Czech Republic, Spain, Ireland, Estonia, Lithuania and the United Kingdom). The cluster is defined by having intermediate values in all dimensions (similar value to the European average). It stands out the high percentage of enterprises which have adopted electronic interaction with the public authorities and other 
enterprises (D3A); and that they have a high percentage of enterprises with the D1, "Provision and connectivity of fundamental ICTs of advanced character" (above European average).

- Cluster 4. Countries with intermediate digital inclusion with high use of the "ICTs for electronic interaction" (Dimension 3B). It is composed of 6 countries (France, Italy, Latvia, Poland, Portugal and Slovakia). They stand out because of a high volume of enterprises which use ICTs for electronic interaction, mainly with the public authorities and other enterprises (D3B, with $53.9 \%$ of enterprises, above average) and for e-invoicing and ecommerce (D2, with $15.6 \%$ of enterprises).

- Cluster 5: Countries with low digital inclusion whose enterprises have not adopted "Use of advanced ICTs for e-commerce" (D2). This cluster comprises 4 countries: Cyprus, Serbia, Hungary and the Republic of Macedonia. The percentage of enterprises is below the European average in all EDDI dimensions except in D3B (electronic interaction with the public authorities and other enterprises).

- Cluster 6. Countries whose enterprises rank last in digital inclusion. This last group is composed of 4 countries: Bulgaria, Greece, Romania and Turkey. They are the countries with the lowest percentage of enterprises which adopt and use ICTs and e-commerce in all Europe (only in one out of three firms) in all dimensions. Therefore, the deficits of digital development in their enterprise sector stand out, especially in the aspects of the most fundamental ICTs, such as the ones related to D1 ("Provision and connectivity of fundamental ICTs of advanced character", only in $45.3 \%$ of enterprises).

\subsubsection{Typology of enterprise digital development in the Spanish regions within the European context}

The discriminant analysis classifies the Spanish regions in 3 of the clusters of European countries. This analysis was performed with the statistical programme IBM SPSS v.24. It was used as a dependent variable the "Belonging to Clusters" for European countries, obtained with the K-means cluster analysis. For their part, the independent variables were the same used in the factor analysis (Table 1) and the number of cases was 32 (countries or NUTSO). The discriminant analysis was conducted with the option Stepwise method ("Wilks' Lambda" and use probability of F.) to remove independent variables that are not significant (multicollinearity) in discriminant functions.

The results of the different verification tests and of the measurement of the goodness of fit of the discriminant model were suitable and they permit the verification of the model (Appendix D): the Box's M Test with $\mathrm{P}=0.003$; the eigenvalues are high, especially in the first function which explains by itself the $76.7 \%$ of variance; the canonical correlations close to 1 : $0.940,0.786$ and 0.640 and the Wilks' Lambda with figures close to 0 . Last, the confusion matrix showed a high accuracy of the discriminant functions obtained since the classifying ability of the model is very high because it properly classifies $87.5 \%$ of the cases.

For their part, the results of the contrast test of Wilks' Lambda show that there are 3 significant independent variables for the model and, therefore, they have been included in 
the discriminant functions. In order of importance, the variables are: "Enterprises connecting to the internet via a mobile broadband connection", "Enterprises sending e-Invoices B2BG" and "Enterprises that Use social networks". It is interesting to highlight that these variables belong to each one of the 3 factors identified by the FA.

The classification functions of the discriminant model were created from Fisher's classification function coefficient (Table D.5, Appendix D). The first function would be:

\section{$F 1=-123.8+2.49 *$ Enterprises connecting to the internet via a mobile broadband connection + 0.84 Enterprises sending e-Invoices B2BG + $0.21^{*}$ Enterprises that Use social networks

And, like this, with the other 5 discriminant functions.

With these values, the Spanish regions were classified into the clusters of European countries obtained. As mentioned, the Spanish regions are included in 3 out of the 6 clusters of European countries according to the degree of digital inclusion, in particular in:

- Cluster 2. Regions with high digital inclusion of enterprises and "Specialised employability in ICTs and social networks": Andalucía, Balears, Canarias, Castilla-La Mancha, Cataluña, Comunitat Valenciana, Extremadura, Madrid, Murcia and La Rioja.

- Cluster 3. Regions with intermediate digital inclusion and low use of "Specialised employability in ICTs and social networks": Aragón, Asturias, Galicia and Navarra.

- Cluster 4. Regions with intermediate digital inclusion with high use of the "ICTs for electronic interaction" (e-administration and/or e-commerce): Cantabria, Castilla y León, Ceuta, Melilla and País Vasco.

\subsubsection{Enterprise digital development and DD by cluster typology of countries and regions}

In Map 2 it can be observed that the geographical distribution of the typology of enterprise digital development of countries and regions have a similarity with that of the EDDI (Map 1). The belonging of a country or region to a cluster is related in almost $75 \%$ to its EDDI (according to the coefficient of determination $\mathrm{R}^{2}$ between both variables). This highlights the relation between EDDI (which reflects "quantity" of digital development) and the cluster typology (which shows a "quality" of digital development).

Indeed, there are countries with high values of EDDI which are included in clusters with a lower digital inclusion due to the excessive weight of some of the dimensions of the index. For example, Spain has a high EDDI (56.2\% of enterprises) but it is classified in cluster 3 , which is characterised by an intermediate digital inclusion. This is because its EDDI is the result of a high percentage of enterprises in the D1 (it has $71.4 \%$ of firms with fundamental ICTs of advanced character, the fourth highest value in Europe). For their part, Malta or Austria have an EDDI lower than Spain (around 55\%) but they belong to cluster 2 (countries and regions with high digital inclusion) since they present high values in all dimensions (above average), especially high in D3A and D1. 
Map 2. Clusters of countries and regions according to enterprise digital development.

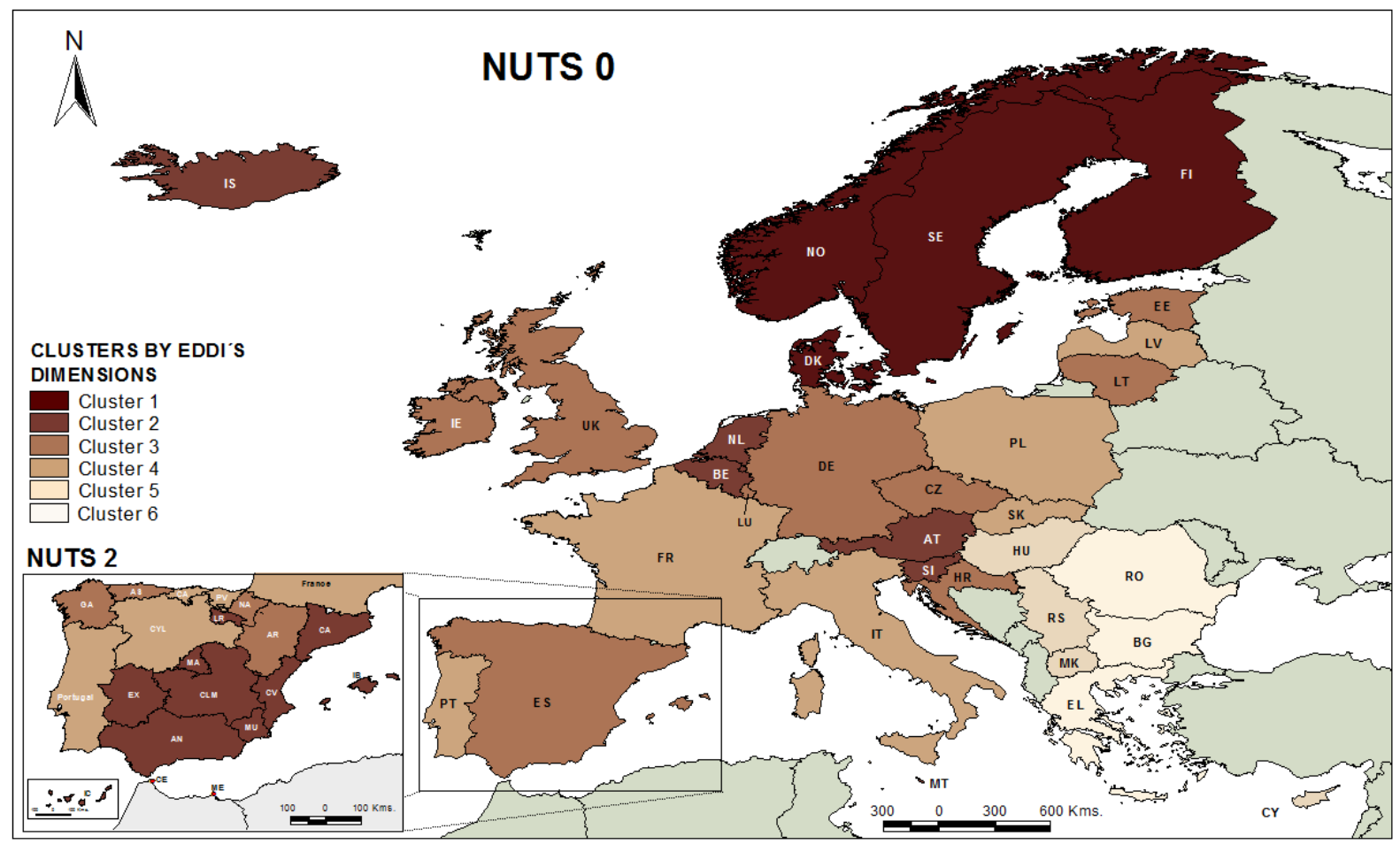

Source: prepared by the authors.

The analysis of DD data according to cluster typology (inter-cluster) reveals that there is an inversely proportional relationship between the DD and the typology of digital inclusion (Table 6 and Map 3). According to the coefficient of determination $\mathrm{R}^{2}$, the variation in the levels of DD depends in a $70 \%$ of the cluster to which they belong. In this way, countries and regions with very high digital inclusion of enterprises (cluster 1 ) have an average difference of $4.5 \%$ of enterprises with respect to the country with the highest EDDI (Finland with a $70.1 \%$ of enterprises). On the contrary, countries and regions whose enterprises rank last in digital inclusion (cluster 6 ) differ an average of $32.6 \%$ with respect to this Nordic country. Table 6 shows that the inverse association between DD and cluster typology also appears in the different EDDI dimensions (with a few exceptions), being D2 the one with the highest difference among countries and regions at enterprise level. On the contrary, it is the D3B the one with lower DD values between clusters, reason why it is revealed as the most homogeneous digital development quality in countries and regions.

Table 6. DD of clusters (in average \% of enterprises).

\begin{tabular}{|c|c|c|c|c|c|c|c|}
\hline & \multicolumn{6}{|c|}{ CLUSTER } & \multirow{2}{*}{ AVERAGE } \\
\hline & 1 & 2 & 3 & 4 & 5 & 6 & \\
\hline Dimension 1 & 4.4 & 7.8 & 8.7 & 12.8 & 18.1 & 32.4 & 13.6 \\
\hline Dimension 2 & 9.3 & 33.7 & 39.9 & 34.2 & 39.9 & 39.0 & 32.9 \\
\hline Dimension 3A & 5.3 & 11.6 & 16.4 & 18.7 & 15.4 & 21.0 & 14.7 \\
\hline Dimension 3B & 4.6 & 8.4 & 10.9 & 8.4 & 10.2 & 20.8 & 10.4 \\
\hline AVERAGE & 4.8 & 13.5 & 16.3 & 17.9 & 22.0 & 32.6 & 17.6 \\
\hline
\end{tabular}

Source: prepared by the authors.

The intra-cluster analysis of the EDDI also shows that Spanish regions present, on average, higher digital development than European countries. Indeed, as shown in Table 7, the NUTS2 
of the clusters 3 and 4 have a higher percentage of enterprises which have implemented ICTs than NUTSO (56.8\% compared to $53.1 \%$, in cluster 3 ; and $55.1 \%$ compared to $49.2 \%$ in cluster 4). However, in cluster 2 percentages are similar (slightly higher for countries, with $56.7 \%$, whereas regions have 56.5\%). Regarding data offered by different dimensions of EDDI, Spanish regions show a higher digital development for D1 and D3B in their own groups. Nevertheless, European countries have a higher digital development in all clusters for D2 and D3A (except in group 4).

Map 3. DD between countries and regions (in average \% of enterprises).

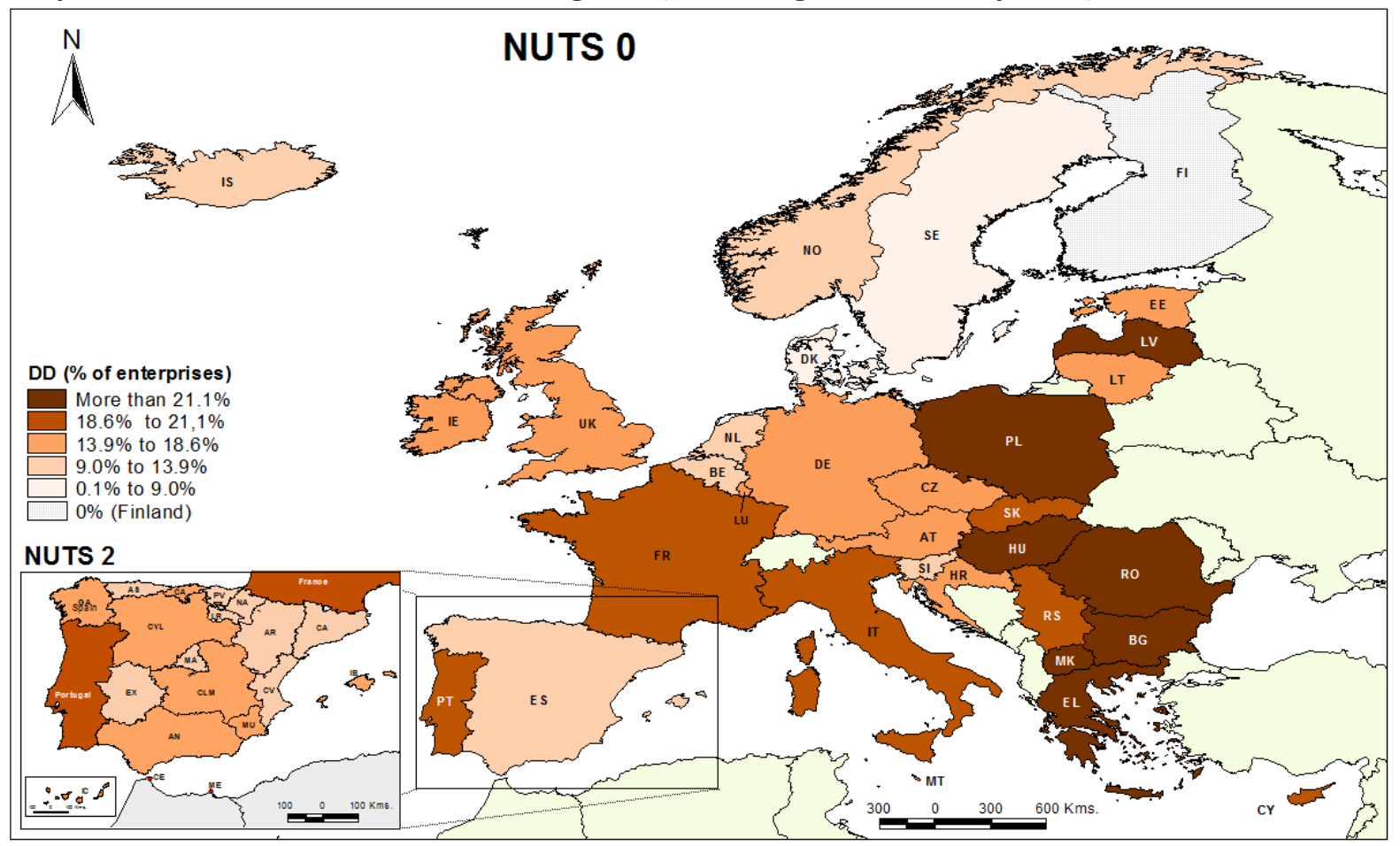

Source: prepared by the authors.

Table 7. Digital dimensions and EDDI of Spanish regions and European countries per clusters (in average \% of enterprises).

\begin{tabular}{ccccccccc}
\hline \multirow{2}{*}{ DIGITAL DEVELOPMENT (EDDI) } & \multicolumn{7}{c}{ CLUSTERS } & \multirow{2}{*}{ AVERAGE } \\
\cline { 3 - 7 } & \multirow{2}{*}{ D1 } & $\mathbf{1}$ & $\mathbf{2}$ & $\mathbf{3}$ & $\mathbf{4}$ & $\mathbf{5}$ & $\mathbf{6}$ & \\
\hline \multirow{2}{*}{ NUTS2 } & & 71,2 & $\mathbf{7 3 , 2}$ & 70,4 & & & 71.4 \\
& Countries & 73,1 & 67,9 & 66,2 & 59,9 & 60,8 & 45,3 & 63.6 \\
\hline \multirow{2}{*}{ D2 } & NUTS2 & & 12,8 & 9,9 & 12,4 & & & 12.1 \\
& Countries & 37,7 & 21,7 & 15,4 & 18,2 & 8,9 & 11,4 & 18.7 \\
\hline \multirow{2}{*}{ D3A } & NUTS2 & & 28,0 & 26,0 & 23,4 & & & 26.3 \\
& Countries & 36,0 & 33,8 & 27,6 & 22,0 & 25,5 & 21,1 & 27.9 \\
\hline \multirow{2}{*}{ D3B } & NUTS2 & & 57,3 & 56,6 & 55,9 & & & 56.8 \\
& Countries & 56,6 & 50,0 & 47,7 & 52,3 & 51,2 & 41,1 & 49.9 \\
\hline \multirow{2}{*}{ Average } & NUTS2 & & $\mathbf{5 6 , 5}$ & $\mathbf{5 6 , 8}$ & $\mathbf{5 5 , 1}$ & & & $\mathbf{5 6 . 2}$ \\
& Countries & $\mathbf{6 4 , 2}$ & $\mathbf{5 6 , 7}$ & $\mathbf{5 3 , 1}$ & $\mathbf{4 9 , 2}$ & $\mathbf{4 8 , 2}$ & $\mathbf{3 7 , 5}$ & $\mathbf{5 2 . 3}$ \\
\hline
\end{tabular}

Source: Prepared by the authors.

We can find the same performance, but inverse, in the intra-group analysis of the DD, as can be verified in Table 8 . Therefore, Spanish regions have a lower DD in the dimensions and 
clusters in which they have shown a bigger digital inclusion (D1 and D3B). European countries offer lower values of divide for D2 in all clusters and for D3A (except in group 3). Therefore, it is verified again that the differences of DD do not depend on the members of a cluster being countries or regions, but rather on their digital inclusion.

Table 8. Digital Divide of the dimensions of EDDI of Spanish regions and European countries per clusters (in average \% of enterprises).

\begin{tabular}{ccccccccc}
\hline \multirow{2}{*}{ DIGITAL DIVIDE (DD) } & \multicolumn{7}{c}{ CLUSTERS } & \multirow{2}{*}{ AVERAGE } \\
\cline { 2 - 7 } & NUTS2 & $\mathbf{1}$ & $\mathbf{2}$ & $\mathbf{3}$ & $\mathbf{4}$ & $\mathbf{5}$ & $\mathbf{6}$ & \\
\hline \multirow{2}{*}{ D1 } & Countries & 4.4 & 9.5 & 4.5 & 7.3 & & & 6.3 \\
& NUTS2 & & 37.6 & 40.5 & 38.0 & & & 38.3 \\
\hline \multirow{2}{*}{ D2 } & Countries & 9.3 & 29.4 & 37.3 & 36.2 & 39.9 & 39.0 & 31.7 \\
& NUTS2 & & 14.1 & 16.2 & 18.8 & & & 15.8 \\
\hline \multirow{2}{*}{ D3A } & Countries & 5.3 & 8.8 & 16.7 & 18.7 & 15.4 & 21.0 & 14.2 \\
& NUTS2 & & 4.7 & 5.4 & 6.0 & & & 5.2 \\
\hline \multirow{2}{*}{ D3B } & Countries & 4.6 & 12.5 & 15.3 & 9.8 & 10.2 & 20.8 & 12.0 \\
& NUTS2 & & $\mathbf{1 3 . 6}$ & $\mathbf{1 3 . 5}$ & $\mathbf{1 5 . 0}$ & & & $\mathbf{1 3 . 9}$ \\
& Countries & $\mathbf{4 . 8}$ & $\mathbf{1 3 . 4}$ & $\mathbf{1 8 . 6}$ & $\mathbf{1 9 . 5}$ & $\mathbf{2 2 . 0}$ & $\mathbf{3 2 . 6}$ & $\mathbf{1 7 . 7}$ \\
\hline \multirow{2}{*}{ Average } & & & & & & & & \\
& & &
\end{tabular}

Source: Prepared by the authors.

\section{DISCUSSION AND CONCLUSIONS}

This research has made it possible to confirm that, within the European context, enterprises with more than 10 employees of the Spanish regions have a medium-high level of digital development. Indeed, as regards EDDI, Spanish regions surpass European countries in almost 4 points in percentage of enterprises with global digital integration (56.2\% of EDDI). Furthermore, regions are located in high positions in the ranking of European EDDI since all (except Melilla), have values above average (53.3\%). On the other hand, Spanish regions show similar values of digital development among them and, therefore, they have a lower DD than the one in the European countries (Maps 1 and 3). These results confirm, according to recent studies (Billon et al., 2016), that there is no defined geographic pattern of DD for European enterprises.

Most Spanish regions belong to the typology of high (cluster 2) or intermediate (cluster 3) digital inclusion of enterprises. The regions reach this position within the European context because they have, on average, a higher volume of firms with "Provision and Connectivity of fundamental ICTs of advanced character" (D1) and with "E-invoicing with the public authorities and other enterprises" (D3B). This suggests that small values of DD among regions are more related to strategies and financial resources at national level than with specific strategies of the regions themselves (Billon et al., 2016).

Spain, according to the Digital Progress Report of the European Commission (2017c), has improved considerably in the provision of fundamental ICTs of advanced character (D1) thanks to the significant increase of the coverage of fixed and fast networks over the last year (from $29 \%$ to $49 \%$ of the territory). This positions the country with values far above EU average. Furthermore, the ICTs for the interaction with public authorities and other 
enterprises (D3B) is not only the dimension where Spain obtains better results at country level, but it is also one of the countries with a higher level of online interaction between the public authorities, the citizens and the enterprises. All this is the result of Law 18/2015 of reusing and transparency of data and of Aporta Project ${ }^{5}$, so that the institutional framework seems to be performing a relevant role (Hughes et al., 2008) for the interaction with the public authorities and other enterprises.

However, Spanish regions also show some weak points of digital development in comparison with European countries. The main deficits can be found in D2 "Use of advanced ICTs for ecommerce (e-invoicing)". This type of ICTs is present in barely more than $12 \%$ of Spanish firms, whereas the European average is of almost $19 \%$ and the countries with very high digital inclusion of enterprises (cluster 1 ) have $41 \%$ of enterprises on average which have incorporated this group of ICTs. The aforementioned Europe's Digital Progress Report (European Commission, 2017c) points out that this weakness can be due to the structure of the Spanish enterprise sector, characterised by a high concentration of SMEs (also pointed out in the RIO National Report 2016 and the Cotec Report, 2016) ${ }^{6}$, a majority of which operate in traditional sectors with low technological content. This characteristic of the Spanish enterprise sector hinders, to a certain extent, the use of advanced ICTs since, according to the research of Tranos and Gillespie (2009), the service sectors and the high and medium-high technology sectors are the most prone to using this type of ICTs and also favour the use of these ICTs by other economic sectors.

To sum up, Spanish regions stand out for having a higher level of digital development than European countries in the ICTs related to infrastructures of internet access and for external interactions (mainly with the public authorities). On the contrary, European countries show higher degree of digital development in the integration of ICTs for e-commerce (and, to a lesser extent, in staff specialised in the use of ICTs). As a result, it is deduced that there is a differentiated performance in the digital dimensions between Spanish and European enterprises. Therefore, the former stand out for the higher presence of some ICTs of induced nature and external to the enterprise since the e-government has a high degree of implementation in all fields of economy (European Union, 2015). However, the implementation of ICTs of inner or own character is related to a performance induced by the market and with the capacities and skills of enterprises for their use (Marenghi and Badillo, 2012). Therefore, in the case of Spanish regions, the degree of digital integration is stimulated by the quality of national policies and the regulatory practices which permit and promote the effective use of ICTs (World Economic Forum INSEAD, 2011).

The results obtained in this piece of work are an original contribution and they increase the scarce regional literature on the adoption and use of ICTs at enterprise level since it provides: a) An indicator at enterprise level (EDDI) for European countries and regions which permits:

\footnotetext{
${ }^{5}$ This project has been propelled by the Central Government since 2005. Its specific aim is to promote the availability of information of the public sector.

${ }^{6}$ According to The Central Business Register (CBR) published by the INE (2017c), 95.7\% of Spanish enterprises have less than 9 employees (micro-enterprises); although $86.7 \%$ of employment is registered in the firms with more than 10 employees.
} 
i) including the multidimensionality of the phenomenon since it has been built based on multivariate statistical methods; ii) comparing if the Spanish regions have the same degree of adoption of ICTs and e-commerce as European countries; and iii) verifying that there is a DD among countries in the EU and Spanish regions related to a typology of digital development; b) A methodology to measure the level of digital development and the DD which is applicable to those countries with ICT data at regional scale; c) A ranking for European countries and Spanish regions according to the integration of ICTs and DD between them; d) A typology of European countries of digital development at enterprise level, and the first classification of regions (NUTS2) within the European context, in particular of the Spanish regions; and last, e) a method whose results can serve to know the importance that the different variables of ICTs have in the measurement of the digital development of countries and regions of the EU in their different dimensions. Thus, European countries and Spanish regions can design policies of digital development and/or assessment of the introduction of the Digital Agenda for Europe, as well as for the Regional Policy of the EU according to the dimensions developed or to be developed.

Nevertheless, this research has some limitations. On the one hand, the number of variables included in the analysis (13) is limited due to the availability of data. The aim set by this piece of work demands to have the same variables and indicators for the analysis and country and region level. The regional analysis of the DD at enterprise level would be more accurate if Eurostat published those indicators at NUTS2 level. If this were the case, the unit of study would have been the European regions (NUTS2) and the results of the statistical analyses would also be stronger (Factor Analysis, Cluster Analysis and Discriminant Analysis). On the other hand, the analyses have been made with statistical data about enterprises with more than 10 employees. In some countries, as it is the case in Spain, the enterprise sector is mainly composed of microenterprises (less than 10 employees). It would be convenient that Eurostat published the data of ICTs of European microenterprises at country and/or region scale so that the national and regional reality of the DD can be addressed more accurately.

According to the mentioned progress, future lines of research are proposed, to delve into the study of the DD at enterprise level at regional scale in Europe. One of these lines would be to investigate the causes of the DD by applying regression techniques to find out which are the factors that have an impact on the regional differences in the introduction of ICTs in the enterprises. This would entail delving into the incidence on DD of different aspects such as the regional enterprise structure, the inner characteristics of enterprises, the level of training of employees, the R\&D and innovation activities, ICT capacities and digital awareness, among others and also including geographic variables related to the regional environment, such as the technological and educational level, the income, the digital policies and other endogenous aspects of the territory.

\section{Acknowledgment}

This study is based on a R\&D project financed by Spanish Ministry of Economy, Industry and Competitiveness. Plan Estatal 2013-2016 Excelencia - Proyectos I+D. Ref: CSO2015-67662. 


\section{REFERENCES}

Bach, M. P., Zoroja, J., \& Vukšić, V. B. (2013a). Determinants of firms' digital divide: A review of recent research. Procedia Technology, 9, 120-128. https://doi.org/10.1016/i.protcy.2013.12.013

Bach, M. P., Zoroja, J., \& Vukšić, V. B. (2013b). Review of corporate digital divide research: A decadal analysis (2003-2012). International Journal of Information Systems and Project Management, 1(4), 41-55. https://doi.org/10.12821/ijispm010403

Bartholomew, D. (2005). Paper or ether? Industry Week, Vol. 254, 2, pp. 26-33

Billon, M., Ezcurra, R., \& Lera-López, F. (2008). The spatial distribution of the internet in the European Union: Does geographical proximity matter?. European Planning Studies, 16(1), 119-142. https://doi.org/10.1080/09654310701748009

Billon, M., Ezcurra, R., \& Lera-López, F. (2009). Spatial effects in website adoption by firms in European regions. Growth and change, 40(1), 54-84. https://doi.org/10.1111/i.1468$\underline{2257.2008 .00461 . x}$

Billon, M., Lera-López, F., \& Marco, R. (2016). ICT use by households and firms in the EU: links and determinants from a multivariate perspective. Review of World Economics, 152(4), 629654. https://doi.org/10.1007/s10290-016-0259-8

Billon, M., Lera-López, F., \& Marco, R. (2017a). Patterns of Combined ICT Use and Innovation in the European Regions. Journal of Global Information Technology Management, 20(1), 2842. https://doi.org/10.1080/1097198X.2017.1280302

Billon, M.; Marco, R.; Lera-López, F. (2017b). Innovation and ICT use by firms and households in the EU: a multivariate analysis of regional disparities. Information Technology and People, 30(2), 424-448. https://doi.org/10.1108/ITP-05-2015-0098

Barzilai-Nahon, K. (2006). Gaps and bits: Conceptualizing measurements for digital divide/s. The information society, 22(5), 269-278. https://doi.org/10.1080/01972240600903953

Bose, R., \& Luo, X. (2011). Integrative framework for assessing firms' potential to undertake Green IT initiatives via virtualization-A theoretical perspective. The Journal of Strategic Information Systems, 20(1), 38-54. https://doi.org/10.1016/i.jsis.2011.01.003

Brown, I., \& Russell, J. (2007). Radio frequency identification technology: An exploratory study on adoption in the South African retail sector. International journal of information management, 27(4), 250-265. https://doi.org/10.1016/j.ijinfomgt.2007.02.007

Bruno, G.; Esposito, E.; Genovese, A.\& Gwebu K.L (2010). A critical analysis of current indexes for digital divide measurement. The Information Society, 27, 16-28. http://dx.doi.org/10.1080/01972243.2010.534364 
Buyya, R., Yeo, C. S., Venugopal, S., Broberg, J., \& Brandic, I. (2009). Cloud computing and emerging IT platforms: Vision, hype, and reality for delivering computing as the 5th utility. Future Generation computer systems, 25(6), 599-616. https://doi.org/10.1016/i.future.2008.12.001

Carlsson B, Jacobsson S, Holmén M \& Ricknea A (2002) Innovation systems: Analytical and methodological issues. Research Policy 31:233-245. https://doi.org/10.1016/S0048$\underline{7333(01) 00138-X}$

Castro J.M (2009): Indicators of Urban Sustainable Development. An Implementation for Andalusia. Free electronic edition. [Indicadores de Desarrollo Sostenible Urbano. Una Aplicación para Andalucía. Edición electrónica gratuita.]. Complete text at www.eumed.net/tesis/jmc/ (Accessed 13 March 2017).

Castaño, E. (2011): Multidimensional indicator for life indicators [Indicador multidimensional de indicadores de vida.] Sociology in its settings [La Sociología en sus escenarios.] pp 5-24

Çilan, Ç. A., Bolat, B. A., \& Coşkun, E. (2009). Analyzing digital divide within and between member and candidate countries of European Union. Government Information Quarterly, 26(1), 98-105. https://doi.org/10.1016/i.giq.2007.11.002

Dutta, S.; Mia, I. (Ed). (2011). Global Information Technology Report 2010-2011 Transformations 2.0. Geneva, Switzerland:World Economic Forum and INSEAD

Fundación Cotec para la Innovación (2016). Informe Cotec 2016. Innovación en España. Madrid:COTEC. http://cotec.es/pdfs/COTEC-informe-2016.pdf (Accessed 20 April 2017).

Eurofound. European Foundation for the Improvement of Living and Working Conditions (2012). European Quality of Life Survey 2012. https://www.eurofound.europa.eu/surveys/european-quality-of-life-surveys/europeanquality-of-life-survey-2012 (Accessed 16 January 2017)

European Union (2015). eGovernment. Using technology to improve public services and democratic participation. European Parliamentary Research Service- EPRS. http://www.europarl.europa.eu/RegData/etudes/IDAN/2015/565890/EPRS IDA(2015)5658 90 EN.pdf (Accessed 8 June 2017)

Eurostat Statistic (2017a).Digital economy and society statistics - enterprises http://ec.europa.eu/eurostat/data/database. (Accessed 10 March 2017).

Eurostat Statistic Explained (2017b). Digital economy and society statistics - enterprises. http://ec.europa.eu/eurostat/statistics-

explained/index.php/Information society statistics - enterprises._(Accessed 10 March 2017). 
Eurostat (2017c). NUTS 2 regions in Spain, 2010 and 2013 http://ec.europa.eu/eurostat/documents/345175/7451602/nuts-map-ES.pdf (Accessed 15 June 2017).

European Commission (2010) A Digital Agenda for Europe. Communication from the Commission to the European Parliament, the Council, the European Economic and Social Committee and the Committee of the Regions. Brussels, 26.8.2010 COM (2010) 245 final/2. http://eur-lex.europa.eu/legal-content/EN/TXT/PDF/?uri=CELEX:52010DC0245R(01)

\&from $=E N$ (Accessed 18 May 2017).

European Commission (2015): Communication from the commission to the European Parliament, the council, the European economic and social committee and the committee of the regions. A Digital Single Market Strategy for Europe. Brussels, 6.5.2015

COM (2015) 192 final. http://eur-lex.europa.eu/legalcontent/EN/TXT/HTML/?uri=CELEX:52015DC0192\&from=ES (Accessed 19 May 2017).

European Commission (2017a): DESI 2016. Digital Economy and Society Index. Methodological note. Directorate-General for Communications Networks, Content and Technology. Bruxelles, Belgique. (Accessed 22 June 2017).

European Commission (2017b). Europe's Digital Progress Report 2017. https://ec.europa.eu/digital-single-market/en/european-digital-progress-report (Accessed 25 April 2017).

European Commission (2017c). Informe sobre el progreso digital en Europa (EDPR) 2017: Perfil de España. https://ec.europa.eu/digital-single-market/en/scoreboard/spain (Accessed 25 April 2017).

Cruz-Jesus, F., Oliveira, T., \& Bacao, F. (2012). Digital divide across the European Union. Information \& Management, 49(6), 278-291. https://doi.org/10.1016/j.im.2012.09.003 (Accessed 7 March 2017).

Hernández-Ortega, B., \& Serrano-Cinca, C. (2009). ¿Qué induce a las empresas a adoptar facturación electrónica? Efecto de las percepciones y del entorno competitivo. Universia Business Review, (24), 96-121.

Hernaus, T., Bach, M.P., \& Vukšić, V.B (2012). Influence of strategic approach to BPM on financial and non-financial performance. Baltic Journal of Management,7(4), 376-396. https://doi.org/10.1108/17465261211272148

Hughes, J., Lang, K. R., \& Vragov, R. (2008). An analytical framework for evaluating peer-topeer business models. Electronic Commerce Research and Applications,7(1), 105-118. https://doi.org/10.1016/i.elerap.2007.01.001

INE (2017a). Encuesta sobre el uso de TIC y comercio electrónico en las empresas. Metodología. Spain, Madrid. 
http://www.ine.es/daco/daco42/comele/metocor.pdf (Accessed 1 February 2017).

INE (2017b): Encuesta sobre el uso de TIC y comercio electrónico en las empresas. http://www.ine.es/dynt3/inebase/es/index.htm?type=pcaxis\&path=/t09/e02/a20152016\&file=pcaxis\&dh=0\&capsel=1. (Accessed 1 February 2017).

INE (2017c): Central Business Register.

http://www.ine.es/dynt3/inebase/en/index.htm?padre=51\&dh=1 (Accessed 1 June 2017).

International Telecommunication Union -ITU- (2003). World telecommunication development report 2003: Access indicators for the information society. International Telecommunications Union, Geneva, Switzerland. http://www.itu.int/net/wsis/tunis/newsroom/stats/WorldTelecomDevelopmentReport2003 E.pdf (Accessed 23 January 2017).

International Telecommunication Union -ITU- (2017). Partnership core list of ICT indicators, as of March 2016. http://www.itu.int/en/ITU-D/Statistics/Documents/coreindicators/CoreList-of-Indicators March2016.pdf (Accessed 23 January 2017).

Marenghi, P., \& Badillo Matos, Á. (2012). Acceso y Agenda Digital en la Unión Europea: el caso de España. En Pérez Alonso, R. y Piedras Feria, E., Una agenda digital: telecomunicaciones y tecnologías de la información en México. México DF: Cámara de Diputados.

Martin, L., \& Omrani, N. (2015). An assessment of trends in technology use, innovative work practices and employees' attitudes in Europe. Applied Economics, 47(6), 623-638. https://doi.org/10.1080/00036846.2014.978072

Mason, S. M., \& Hacker, K. L. (2003). Applying communication theory to digital divide research. It \& Society, 1(5), 40-55.

Moroz, M. (2017). The Level of Development of the Digital Economy in Poland and Selected European Countries: A Comparative Analysis. Foundations of Management, 9(1), 175-190. https://doi.org/10.1515/fman-2017-0014

Nardo, M., Saisana, M., Saltelli, A., Tarantola, S., Hoffman, A., \& Giovannini, E. (2005). Handbook on constructing composite indicators. France: OECD, 108 p. http://dx.doi.org/10.1787/533411815016. https://doi.org/10.1787/533411815016 Nunnally, J. (1978). Psychometric theory, 2.

OECD-Organization for Economic Cooperation and Development (2001): Understanding The Digital Divide. Paris: OECD Publications. https://www.oecd.org/sti/1888451.pdf (Accessed 24 January 2017).

OECD-Organization for Economic Cooperation and Development (2008): Handbook on Constructing Composite Indicators: Methodology and User Guide Joint Research Center (JRC) 
of the European Commission. Paris: OECD. https://www.oecd.org/std/42495745.pdf (Accessed 25 January 2017).

Pick, J. B., \& Azari, R. (2011). A global model of technological utilization based on governmental, business-investment, social, and economic factors. Journal of Management Information Systems, 28(1), 49-84. https://doi.org/10.2753/MIS0742-1222280103

Poza,C \& Fernández, J. An approach to building a multidimensional poverty indicator. Which are the risk areas in Spain? [Una aproximación a la construcción de un indicador de pobreza multidimensional. Cuáles son los focos de riesgo en España.] J. Quant. Methods Bus Econ. [Revista de métodos cuantitativos para la economía y la empresa.], 10(2010), pp. 43-72. https://www.upo.es/revistas/index.php/RevMetCuant/article/view/2164

(Accessed 8 January 2017)

Rovira, S., Santoleri, P., \& Stumpo, G. (2013). Incorporación de TIC en el sector productivo: uso y desuso de las políticas públicas para favorecer su difusión. Entre mitos y realidades. TIC, políticas públicas y desarrollo productivo en América Latina. Santiago: CEPAL, 2013. LC/L. 3600 p. $17-54$

Sánchez-Moral, S. (2015). Territorio, transformación productiva, equidad y redes. Revista de Estudios Andaluces, 32, 49-75. https://doi.org/10.12795/rea.2015.i32.03

Schlichter, B. R., \& Danylchenko, L. (2014). Measuring ICT usage quality for information society building. Government Information Quarterly, 31(1), 170-184. https://doi.org/10.1016/i.giq.2013.09.003

Schuschny, A., \& Soto, H. (2009). Guía metodológica Diseño de indicadores compuestos de desarrollo sostenible. Santiago de Chile: Naciones Unidas- CEPAL

Skrinjar, R., Bosilj Vuksic, V., \& Indihar Stemberger, M. (2010). Adoption of Business Process Orientation Practices: Slovenian and Croatian Survey. Business Systems Research, 1(1-2), 519. https://doi.org/10.2478/v10305-012-0022-0

Soliman,F . \& Youssef,M.A. (2003): Internet-based e-commerce and its impact on manufacturing and business operations, Industrial Management \& Data systems, Vol. 103 Issue: 8, pp.546-55. https://doi.org/10.1108/02635570310497594

Stapleton, J. (1997). DSDM, dynamic systems development method: the method in practice. Cambridge: University Press.

Spurge, V., \& Roberts, C. (2005). Broadband technology: An appraisal of government policy and use by small-and medium-sized enterprises.Journal of Property Investment \& Finance, 23(6), 516-524. https://doi.org/10.1108/14635780510626556

Tranos, E., \& Gillespie, A. (2009). The spatial distribution of Internet backbone networks in Europe: a metropolitan knowledge economy perspective. European urban and regional studies, 16(4), 423-437. https://doi.org/10.1177/0969776409340866 
Van Dijk, J.A.G.M. (2006). Digital Divide Research, Achievements and Shortcomings. Poetics, 34(4-5), 221-235. https://doi.org/10.1016/i.poetic.2006.05.004

Vehovar, V. Sicherl, P., Husing, T.; Dolnicar, V (2006). Methodological challenges of digital divide measurements. The Information Society, 22, 2006, pp. 279-290. https://doi.org/10.1080/01972240600904076

Vicente-Cuervo, M.R., \& López-Menéndez, A. J. (2006). A multivariate framework for the analysis of the digital divide: Evidence for the European Union-15. Information \& Management, 43(6), 756-766. https://doi.org/10.1016/i.im.2006.05.001

Vicente, M. R., \& López, A. J. (2010). A multidimensional analysis of the disability digital divide: Some evidence for Internet use. The Information Society, 26(1), 48-64. https://doi.org/10.1080/01615440903423245

Vicente, M. R., \& López, A. J. (2011). Assessing the regional digital divide across the European Union-27. Telecommunications Policy, 220-237. https://doi.org/10.1016/i.telpol.2010.12.013

Vu, K.M. (2011). ICT as a Source of Economic Growth in the Information Age: Empirical Evidence from the 1996-2005 Period. Telecommunications Policy, 35(4), 357-372u, 2011. https://doi.org/10.1016/i.telpol.2011.02.008

World Economic Forum (2017). Shaping the Future of Digital Economy and Society. https://www.weforum.org/system-initiatives/the-digital-economy-and-society. (Accessed 10 June 2017).

World Bank (2012). Knowledge Economy Index. http://knoema.es/WBKEI2013/knowledgeeconomy-index-world-bank-2012 (Accessed 18 January 2017).

Yu, L. (2006). Understanding Information Inequality: Making Sense of the Literature of the Information and Digital Divides. Journal of Librarianship and Information Science, 38(4), 229252. https://doi.org/10.1177/0961000606070600

Zoroja, J. (2011). Internet, E-Commerce and E-Government: Measuring The Gap Between European Developed and PostCommunist Countries. Interdisciplinary Description of Complex Systems, 9(2), 119-133.

Zoroja, J., \& Bach, M.P (2016). Impact of information and communication technology to the competitiveness of European countries-cluster analysis approach. Journal of theoretical and applied electronic commerce research,11(1), i-x. https://doi.org/10.4067/S0718$\underline{18762016000100001}$ 


\section{APPENDIX A.}

\section{A.1. NUTSO and NUTS2 included in research work.}

\begin{tabular}{|c|c|c|c|}
\hline NUTSO & CODE & NUTS2 & CODE \\
\hline Finland & $\mathrm{FI}$ & Madrid, Comunidad de & MA \\
\hline Denmark & DK & Cataluña & CA \\
\hline Sweden & SE & Comunidad Valenciana & $\mathrm{CV}$ \\
\hline Norway & NO & Rioja, La & LR \\
\hline Slovenia & SI & Extremadura & EX \\
\hline Netherlands & NL & Andalucía & AN \\
\hline Iceland & IS & Balears, Illes & IB \\
\hline Belgium & $\mathrm{BE}$ & Murcia, Región de & $\mathrm{MU}$ \\
\hline Malta & MT & Canarias & IC \\
\hline Austria & AT & Castilla-La Mancha & CLM \\
\hline Spain & ES & Aragón & $A R$ \\
\hline Lithuania & LT & Navarra, Comunidad Foral de & NA \\
\hline Estonia & EE & Asturias, Principado de & AS \\
\hline Ireland & $\mathrm{IE}$ & Galicia & GA \\
\hline United Kingdom & UK & País Vasco & PV \\
\hline Luxembourg & LU & Ceuta & CE \\
\hline Czech Republic & $\mathrm{CZ}$ & Castilla y León & CYL \\
\hline Germany & $\mathrm{DE}$ & Cantabria & $\mathrm{CA}$ \\
\hline Croatia & $\mathrm{HR}$ & Melilla & ME \\
\hline Portugal & PT & & \\
\hline Slovakia & SK & & \\
\hline France & FR & & \\
\hline Italy & IT & & \\
\hline Latvia & LV & & \\
\hline Poland & PL & & \\
\hline Cyprus & $\mathrm{CY}$ & & \\
\hline Serbia & RS & & \\
\hline Hungary & $\mathrm{HU}$ & & \\
\hline Republic of Macedonia & MK & & \\
\hline Greece & EL & & \\
\hline Bulgaria & BG & & \\
\hline Romania & RO & & \\
\hline
\end{tabular}

Source: Eurostat (2017c). NUTS 2 regions in Spain, 2010 and 2013

http://ec.europa.eu/eurostat/documents/345175/7451602/nuts-map-ES.pdf (Accessed 15 June 2017). 


\section{A.2. Definition and reference year of the variables used.}

\begin{tabular}{|c|c|c|c|}
\hline VARIABLE & DEFINITION & SOURCE & YEAR \\
\hline $\begin{array}{l}\text { Enterprises with fixed } \\
\text { broadband access }\end{array}$ & $\begin{array}{l}\text { Broadband: network able to reach high speed of transmission (e.g. DSL connection, } \\
\text { networks of cable and fiber optic technology and other fixed connections). }\end{array}$ & INE, 2017a & $\begin{array}{l}2013 \text { for all countries except } \\
\text { Serbia (2014) }\end{array}$ \\
\hline $\begin{array}{l}\text { Enterprises connecting to } \\
\text { the internet via a mobile } \\
\text { broadband connection. }\end{array}$ & $\begin{array}{l}\text { Type of internet connection through the next mobile devices; portable computers (e.g. } \\
\text { tablet, notebook, netbook, laptop, ultra-mobile PC, ...) and other mobile devices (e.g. } \\
\text { smartphone, PDA phone,...) }\end{array}$ & INE, 2017a & $\begin{array}{l}\text { 2015/16 for all countries except } \\
\text { Iceland (2014) and Serbia (2014) }\end{array}$ \\
\hline $\begin{array}{l}\text { Enterprises giving portable } \\
\text { devices for a mobile } \\
\text { connection to the internet } \\
\text { to their employees. }\end{array}$ & $\begin{array}{l}\text { Availability, on the part of enterprises, of mobile devices which permit internet connection: } \\
\text { portable computers (notebook, netbook, laptop, tablet, PC,...) and other portable devices } \\
\text { (smartphone, PDA phone,...) }\end{array}$ & INE, 2017a & $\begin{array}{l}\text { 2015/16 for all countries except } \\
\text { Serbia (No Data) }\end{array}$ \\
\hline $\begin{array}{l}\text { Enterprises that employ ICT } \\
\text { specialists }\end{array}$ & $\begin{array}{l}\text { People whose main job is ICTs and who are able to face a wide range of tasks related to } \\
\text { corporate computer systems. }\end{array}$ & $\begin{array}{l}\text { Eurostat, } \\
2017 a\end{array}$ & $\begin{array}{l}\text { 2015/16 for all countries except } \\
\text { Iceland (2014) }\end{array}$ \\
\hline $\begin{array}{l}\text { Enterprises having a web } \\
\text { site or homepage. }\end{array}$ & $\begin{array}{l}\text { A website or web site is a space (location) in the World Wide Web which contains } \\
\text { documents (web pages) hierarchically organised. }\end{array}$ & $\begin{array}{l}\text { Eurostat, } \\
2017 a .\end{array}$ & $\begin{array}{l}\text { 2015/16 for all countries except } \\
\text { Iceland (2014) }\end{array}$ \\
\hline Use social networks & $\begin{array}{l}\text { They are applications based on internet technologies or communication platforms to } \\
\text { connect, create or exchange content online with clients, suppliers/partners or within the } \\
\text { company itself in the exercise of the activity itself, such as social networks, blogs, sites } \\
\text { where multimedia content can be exchanged or wikis. }\end{array}$ & INE, 2017a & $\begin{array}{l}\text { 2015/16 for all countries except } \\
\text { Iceland (2014) and Serbia (2014) }\end{array}$ \\
\hline The use of cloud computing & $\begin{array}{l}\text { Cloud computing includes two components: cloud infrastructure and software applications. } \\
\text { The first consists of the hardware resources necessary to support cloud services provided } \\
\text { and normally they include components of the server, storage and network. The second } \\
\text { component is referred to the software applications and the power of calculation to run } \\
\text { enterprise applications, as provided through internet by third parties. }\end{array}$ & INE, 2017a & $\begin{array}{l}\text { 2015/16 for all countries except } \\
\text { Iceland (2014) }\end{array}$ \\
\hline $\begin{array}{l}\text { Persons employed using } \\
\text { computers. }\end{array}$ & Computer provision of enterprise staff who use computers with business purposes. & INE, 2017a & $\begin{array}{l}\text { 2015/16 for all countries except } \\
\text { Denmark (2015); France (2015); } \\
\text { Latvia (2010); Luxembourg (No } \\
\text { Data); Malta (2014); Austria } \\
\text { (2014); Sweden (2010); Iceland } \\
\text { (2010); Serbia (2014) }\end{array}$ \\
\hline $\begin{array}{l}\text { Enterprises who have ERP } \\
\text { software package to share } \\
\text { information between } \\
\text { different functional areas }\end{array}$ & $\begin{array}{l}\text { ERP (Enterprise Resource Planning). Set of computer tools which permit managing, in an } \\
\text { integrated way, the processes and information corresponding to the different areas of } \\
\text { business of an enterprise. Generally, an ERP system integrates the management of planning } \\
\text { areas, provisioning, logistics, sales, marketing, relationship with the client, finances and } \\
\text { human resources. }\end{array}$ & INE, 2017a & $\begin{array}{l}\text { Sweden (2014); Iceland (2014); } \\
\text { Serbia (2014) }\end{array}$ \\
\hline
\end{tabular}




\begin{tabular}{|c|c|c|c|}
\hline $\begin{array}{l}\text { Enterprises sending e- } \\
\text { Invoices B2BG, suitable for } \\
\text { automated processing }\end{array}$ & $\begin{array}{l}\text { E-invoices to other enterprises or public authorities which permit their automatic } \\
\text { processing (e.g. EDI, UBL, XML.). }\end{array}$ & INE, 2017a & $\begin{array}{l}\text { 2015/16 for all countries except } \\
\text { Iceland (2014); Serbia (2014) }\end{array}$ \\
\hline $\begin{array}{l}\text { Enterprises receiving e- } \\
\text { Invoices, suitable for } \\
\text { automated processing }\end{array}$ & $\begin{array}{l}\text { E-invoices to other enterprises which permit their automatic processing (e.g. EDI, UBL, } \\
\mathrm{XML} \text {.). }\end{array}$ & INE, 2017a & $\begin{array}{l}\text { 2015/16 for all countries except } \\
\text { Iceland (2014); Serbia (2014) }\end{array}$ \\
\hline $\begin{array}{l}\text { Enterprises sending invoices } \\
\text { to other enterprises or } \\
\text { public authorities (B2BG) }\end{array}$ & $\begin{array}{l}\text { Interaction with the public authorities through the internet to obtain information, return } \\
\text { completed forms, declare taxes, contributions to the social security, payments, etc. }\end{array}$ & INE, & $\begin{array}{l}\text { 2015/16 for all countries except } \\
\text { Ireland (2014); Italy (No Data); } \\
\text { Iceland (2014); Serbia (No Data) }\end{array}$ \\
\hline $\begin{array}{l}\text { Pay to advertise on the } \\
\text { internet }\end{array}$ & $\begin{array}{l}\text { Internet. International network for the exchange of information, based on the connection } \\
\text { of multiple networks and multiple servers with multiple users by means of standardised } \\
\text { protocols of information exchange. }\end{array}$ & INE, 2017a & $\begin{array}{l}\text { 2015/16 for all countries except } \\
\text { Iceland (2014); Serbia (2014) }\end{array}$ \\
\hline
\end{tabular}

Source: Prepared by the authors. 


\section{A.3. Statistical classification of economic activities in the European Community (NACE). ICT usage in enterprises.}

Reference Metadata in Euro SDMX Metadata Structure (ESMS)

Compiling agency: Eurostat, the statistical office of the European Union

Coverage - sector NACE Rev 2 (as of 2009, back-casting for the years 2003-2008).

\section{Compulsory:}

- C10-C18: Manufacture of products based on: food, beverages, tobacco, textile, leather, wood, pulp and paper; publishing and printing.

- C19-C23: Manufacture of petroleum, chemical, pharmaceutical, rubber, plastic products and of other non-metallic mineral products.

- C24-C25: Manufacture of basic metals and fabricated metal products, except machinery and equipment.

- C26-C33: Manufacture of computers, electric and optical products, electrical equipment, machinery and equipment n.e.c, motor vehicles, other transport equipment, furniture, other manufacturing, repair and installation of machinery and equipment.

- D35-E39: Production and distribution of electricity, gas, steam and air conditioning; water supply, sewerage, waste management and remediation activities.

- F41-F43: Construction.

- G45-G47: Wholesale and retail trade; repair of motor vehicles and motorcycles.

- H49-H53: Transport and storage.

- 155: Accommodation.

- I56: Food and beverage service activities.

- J58-J63: Information and communication.

- L68: Real estate activities.

- L69-M74: Professional, scientific and technical activities, except veterinary activities.

- N77-N82: Administrative and support service activities.

- N79: Travel agency; tour operator reservation service and related activities.

- S95.1: Repair of computers and communication equipment (added since 2010).

In 2010, NACE Rev 2 group S95.1 referring to "Repair of computers and communication equipment" was added to the scope for the enterprise survey and is hence included in the 2010 European aggregates (10_C10_S951_XK, total of all economic activities covered without financial sector). Group 95.1 was not included in EU aggregates of previous years (10_C10_N82_XK, total of all economic activities without financial sector and without group 95.1). Comparability of 2010 EU aggregates (10_C10_N82_XK, excluding the group 95.1) with previous years is limited due to confidential data that are not included when calculating the aggregates.

Source: Eurostat, 2017. http://ec.europa.eu/eurostat/cache/metadata/EN/isoc_e_esms.htm 


\section{A.4. Statistical summary of the main ICT variables used.}

\begin{tabular}{|c|c|c|c|c|c|}
\hline Variables & Average & $\begin{array}{l}\text { Standard } \\
\text { deviation }\end{array}$ & Minimun & Maximun & $\begin{array}{c}\text { Total } \\
\text { observations }{ }^{1}\end{array}$ \\
\hline $\begin{array}{l}\text { Enterprises use DSL or other fixed broadband } \\
\text { connection }\end{array}$ & 91.4 & 6.2 & 72.0 & 99.0 & 51.0 \\
\hline $\begin{array}{l}\text { Enterprises connecting to the internet via a } \\
\text { mobile broadband connection }\end{array}$ & 70.1 & 11.4 & 41.0 & 94.0 & 51.0 \\
\hline $\begin{array}{l}\text { Enterprises giving portable devices for a mobile } \\
\text { connection to the internet to their employees }\end{array}$ & 72.8 & 13.0 & 41.0 & 98.2 & 51.0 \\
\hline $\begin{array}{l}\text { Enterprises having a web site or homepage } \\
\text { Enterprises receiving e-Invoices, suitable for }\end{array}$ & 75.6 & 12.3 & 42.0 & 95.0 & 51.0 \\
\hline automated processing & 30.0 & 14.5 & 2.5 & 70.0 & 50.0 \\
\hline $\begin{array}{l}\text { Enterprises sending e-Invoices B2BG, suitable } \\
\text { for automated processing }\end{array}$ & 20.8 & 17.3 & 3.0 & 72.0 & 50.0 \\
\hline $\begin{array}{l}\text { Buy cloud computing services used over the } \\
\text { internet }\end{array}$ & 22.3 & 13.4 & 4.0 & 57.0 & 51.0 \\
\hline Enterprises that employ ICT specialists & 21.1 & 5.2 & 11.0 & 35.0 & 51.0 \\
\hline Enterprises that use social networks & 45.0 & 13.6 & 23.0 & 70.0 & 51.0 \\
\hline Persons employed using computers & 53.4 & 14.9 & 29.0 & 100.0 & 51.0 \\
\hline $\begin{array}{l}\text { Enterprises sending invoices to other } \\
\text { enterprises or public authorities (B2BG) }\end{array}$ & 79.8 & 12.5 & 45.0 & 99.0 & 49.0 \\
\hline $\begin{array}{l}\text { Enterprises who have ERP software package } \\
\text { Enterprises that pay to advertise on the }\end{array}$ & 31.8 & 11.8 & 10.0 & 56.0 & 51.0 \\
\hline internet & 27.2 & 7.6 & 12.0 & 46.0 & 51.0 \\
\hline
\end{tabular}

(1) The missing values were replaced by the average of the rest of observations. Source: Prepared by the authors. 


\section{APPENDIX B. FACTOR ANALISYS}

\section{B.1 KMO and Bartlett test.}

\begin{tabular}{|c|c|c|}
\hline & \multirow{2}{*}{$\begin{array}{r}.740 \\
264.727\end{array}$} \\
\hline & & \\
\hline & $\begin{array}{ll}\text { Bartlett's test of sphericity } & \text { Approx. Chi-quadrate } \\
\text { gl }\end{array}$ & 55 \\
\hline & & .000 \\
\hline
\end{tabular}

\section{B.2 Communalities.}

\begin{tabular}{|l|r|r|}
\hline & Initial & Extraction \\
\hline SMEAN(Enterprisesgivingportabledevices) & 1.000 & .817 \\
SMEAN(Enterpriseshavingawebsiteorhomepage) & 1.000 & .836 \\
SMEAN(EnterprisesuseDSLfixedbroadbandconnection) & 1.000 & .836 \\
SMEAN(Enterprisesviaamobilebroadband) & 1.000 & .859 \\
SMEAN(Usesocialnetworks) & 1.000 & .707 \\
SMEAN(Buycloudcomputings) & 1.000 & .902 \\
SMEAN(EnterprisesICTspecialists) & 1.000 & .645 \\
SMEAN(Personsusingcomputers) & 1.000 & .808 \\
SMEAN(EnterprisessendingAAPP) & 1.000 & .738 \\
SMEAN(Enterprisessendinge-InvoicesB2B) & 1.000 & .780 \\
SMEAN(Enterprisesreceivinge-Invoices) & 1.000 & .785 \\
\hline
\end{tabular}

Extraction Method: Principal Component Analysis.

\section{B.3 Total Variance Explained.}

\begin{tabular}{|l|r|r|r|}
\hline \multirow{2}{*}{ Component } & \multicolumn{3}{|c|}{ Initial Eigenvalues } \\
\cline { 2 - 4 } & Total & \% de variance & \% cumulative \\
\hline 1 & 5.521 & 50.193 & 50.193 \\
3 & 1.865 & 16.958 & 67.150 \\
4 & 1.327 & 12.060 & 79.210 \\
5 & .751 & 6.828 & 86.038 \\
6 & .421 & 3.831 & 89.869 \\
7 & .350 & 3.177 & 93.046 \\
8 & .290 & 2.640 & 95.687 \\
9 & .234 & 2.123 & 97.810 \\
10 & .111 & 1.013 & 98.823 \\
11 & .078 & .709 & 99.532 \\
& .051 & .468 & 100.000 \\
\hline
\end{tabular}

Extraction Method: Principal Component Analysis. 


\section{APPENDIX C. CLUSTER ANALISYS}

\section{C.1 Hierarchical Clustering Analysis. Dendrogram.}

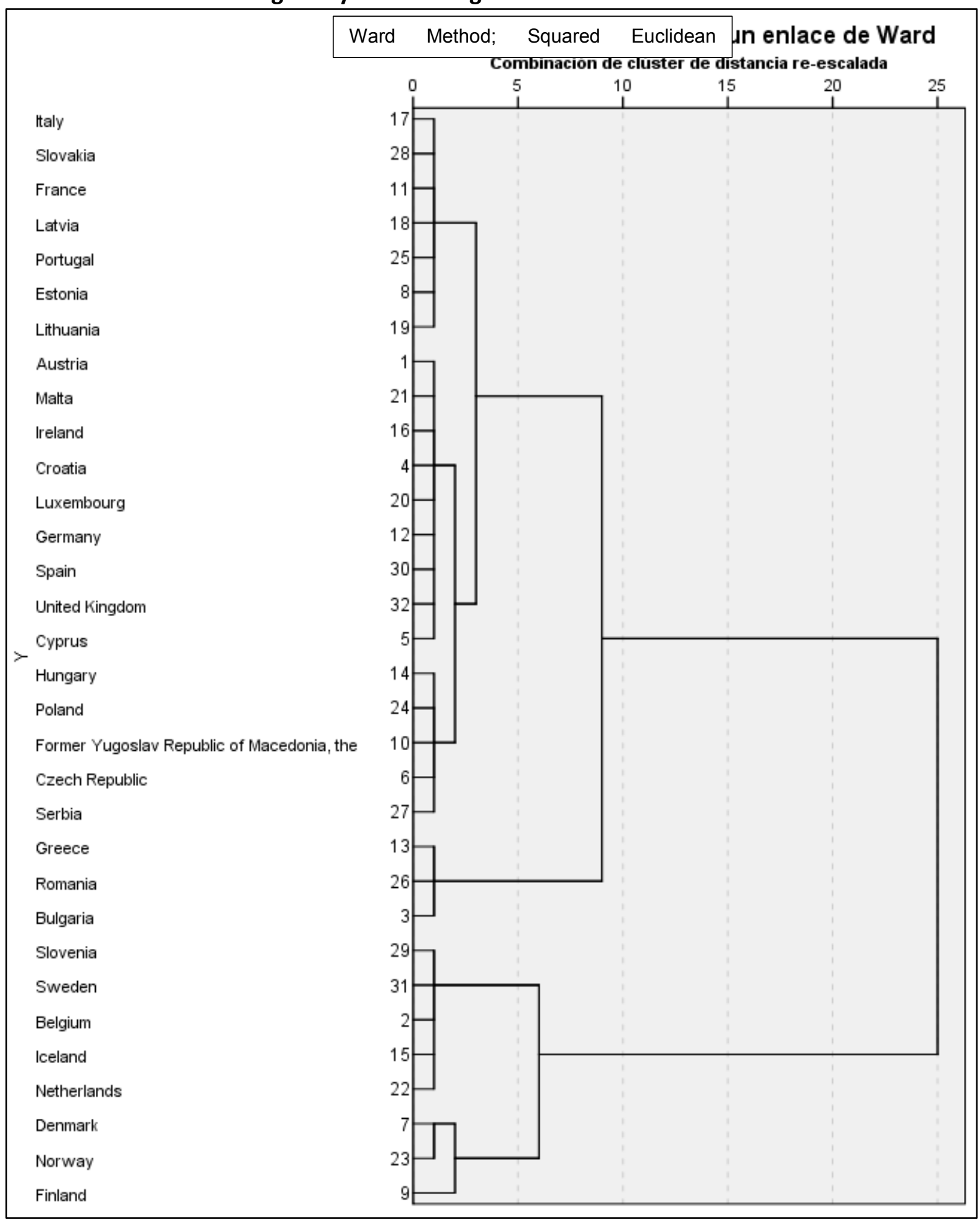

Ward Method; Squared Euclidean distance. 


\section{APPENDIX D. DISCRIMINANT ANALYSIS.}

D.1 M. de Box Test ${ }^{\text {a }}$

\begin{tabular}{|c|c|c|}
\hline \multirow{5}{*}{$\begin{array}{l}\text { M de Box } \\
F\end{array}$} & & 49,230 \\
\hline & Approx. & 1.903 \\
\hline & gl1 & 18 \\
\hline & $\mathrm{g} / 2$ & 728.853 \\
\hline & Sig. & 0.003 \\
\hline
\end{tabular}

a. The logarithms of determinants is 12,622

D.2 Eigenvalues.

\begin{tabular}{|l|r|r|r|r|}
\hline Function & Eigenvalue & \% de variance & \% cumulative & Canonica Correlation \\
\hline 1 & $7.615^{\mathrm{a}}$ & 76.7 & 76.7 & 0.940 \\
\hline 2 & $1.619^{\mathrm{a}}$ & 16.3 & 93.0 & 0.786 \\
\hline 3 & $0.695^{\mathrm{a}}$ & 7.0 & 100.0 & 0.640 \\
\hline
\end{tabular}

a. First 3 canonical discriminant functions were used in the analysis.

D.3 Wilks' Lambda.

\begin{tabular}{|l|r|r|r|l|}
\hline Test of Function(s) & Wilks' Lambda & Chi-square & gl & Sig. \\
\hline 1 to 3 & 0.026 & 96.561 & 15 & 0.000 \\
\hline 2 to 3 & 0.225 & 39.493 & 8 & 0.000 \\
\hline 3 & 0.590 & 13.980 & 3 & 0.003 \\
\hline
\end{tabular}

D.4 Variables in the analysis ${ }^{a, b, c, d}$

\begin{tabular}{|c|c|c|c|c|c|c|c|c|c|}
\hline \multirow[t]{3}{*}{ Step } & \multirow[t]{3}{*}{ In the analysis } & \multicolumn{8}{|c|}{ Wilks' Lambda } \\
\hline & & \multirow[t]{2}{*}{ Est. } & \multirow[t]{2}{*}{ gl1 } & \multirow[t]{2}{*}{ gl2 } & \multirow[t]{2}{*}{$\mathrm{g} \mid 3$} & \multicolumn{4}{|c|}{ F exact } \\
\hline & & & & & & Est. & gl1 & $\mathrm{g} / 2$ & Sig. \\
\hline 1 & $\begin{array}{l}\text { Enterprises giving portable } \\
\text { devices for a mobile } \\
\text { connection }\end{array}$ & 0.171 & 1 & 5 & 26.0 & 25.217 & 5 & 26.0 & 0.00 \\
\hline 2 & $\begin{array}{l}\text { Enterprises sending e- } \\
\text { Invoices B2BG }\end{array}$ & 0.069 & 2 & 5 & 26.0 & 13.99 & 10 & 50.0 & 0.00 \\
\hline 3 & $\begin{array}{l}\text { Enterprises that use social } \\
\text { networks }\end{array}$ & 0.026 & 3 & 5 & 26.0 & 12.19 & 15 & 66.65 & 0.00 \\
\hline
\end{tabular}

a. Maximum number of steps is 26 .

b. Minimum $\mathrm{F}$ to enter is 3.84 .

c. Maximum $\mathrm{F}$ to remove is 2.71

d. Minimum tolerance F level or VIN are insufficient to continue the calculations.

\section{D.5 Canonical Discriminant Function Coefficients.}

\begin{tabular}{|l|r|r|r|}
\hline Firms that & \multicolumn{3}{|c|}{ Function } \\
\cline { 2 - 4 } & \multicolumn{1}{|c|}{2} & \multicolumn{1}{|c|}{3} \\
\hline Enterprises giving portable devices & 0.621 & -0.805 & 0.115 \\
Enterprises sending e-Invoices B2BG & 0.578 & 0.608 & 0.634 \\
Enterprises that use social networks & 0.590 & 0.654 & -0.614 \\
\hline
\end{tabular}

Unstandardized coefficients 
D.6 Canonical Discriminant Function Coefficients.

\begin{tabular}{|l|r|r|r|r|r|r|}
\hline & \multicolumn{7}{|c|}{ Functions } \\
\cline { 2 - 7 } & \multicolumn{1}{|c|}{1} & \multicolumn{1}{c|}{2} & \multicolumn{1}{c|}{3} & \multicolumn{1}{c|}{4} & \multicolumn{1}{c|}{5} & 6 \\
\hline $\begin{array}{l}\text { Enterprises giving portable devices for a } \\
\text { mobile connection }\end{array}$ & 2.49 & 2.77 & 1.44 & 2.32 & 2.17 & 2.50 \\
\hline Enterprises sending e-Invoices B2BG & 0.84 & 1.05 & 0.48 & 0.49 & 0.69 & 0.52 \\
\hline Enterprises that use social networks & 0.21 & 0.63 & 0.04 & 0.07 & 0.01 & -0.01 \\
\hline (Constant) & -123.8 & -179.3 & -42.31 & -93.01 & -91.06 & -105.8 \\
\hline
\end{tabular}

Unstandardized Coefficients

\section{D.7 Classification Results ${ }^{\mathrm{a}}$}

\begin{tabular}{|c|c|c|c|c|c|c|c|c|c|}
\hline & \multirow{2}{*}{ Cluster } & \multicolumn{6}{|c|}{ Predicted group membership } & \multirow[t]{2}{*}{ Total } \\
\hline & & & 1 & 2 & 3 & 4 & 5 & 6 & \\
\hline \multirow{12}{*}{ 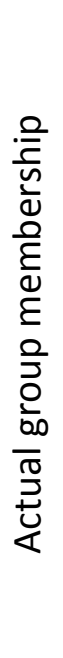 } & \multirow{6}{*}{ 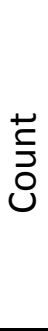 } & 1 & 8 & \multirow{6}{*}{3} & \multirow{6}{*}{3} & \multirow{6}{*}{$\begin{array}{l}7 \\
1 \\
2\end{array}$} & \multirow{6}{*}{3} & \multirow[b]{6}{*}{4} & \multirow{6}{*}{$\begin{array}{l}8 \\
3 \\
3 \\
8 \\
4 \\
6\end{array}$} \\
\hline & & 2 & & & & & & & \\
\hline & & 3 & & & & & & & \\
\hline & & 4 & & & & & & & \\
\hline & & 5 & & & & & & & \\
\hline & & 6 & & & & & & & \\
\hline & & 1 & 100.0 & & , & , & , & , & 100.0 \\
\hline & & 2 & & 100.0 & & , & , & , & 100.0 \\
\hline & 10 & 3 & & & 100,0 & , & , & , & 100.0 \\
\hline & & 4 & & & & 87.5 & . & 12.5 & 100.0 \\
\hline & & 5 & . & ， & ， & 25.0 & 75.0 & . & 100.0 \\
\hline & & 6 & & & , & 33.3 & & 66.7 & 100.0 \\
\hline
\end{tabular}

a. $87.5 \%$ original grouped cases correctly classified. 